\title{
Physical Volcanology of Continental Large Igneous Provinces: Update and Review
}

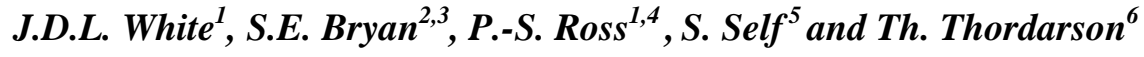 \\ ${ }^{1 .}$ Department of Geology, University of Otago, PO Box 56, Dunedin, New Zealand. \\ ${ }^{2 .}$ Department of Geology \& Geophysics, Yale University, PO Box 208109 New Haven CT 06520-8109 \\ USA. \\ 3. Now at: Centre for Earth and Environmental Science Research, School of Earth Sciences and \\ Geography, Kingston University, Penrhyn Road, Kingston upon Thames, Surrey KT1 2EE, United \\ Kingdom. \\ 4. Now at: INRS-ETE, 490, rue de la Couronne, Québec (QC) G1K 9A9 Canada \\ 5. Open University, Volcano Dynamics Group, Department of Earth Sciences, The Open University, \\ Milton Keynes, MK7 6AA, UK. \\ ${ }^{6}$ School of Earth Science, University of Edinburgh, Grant Institute, The King's Buildings, West Mains \\ Road, Edinburgh, EH9 3JW, UK
}

Email addresses: james.white@stonebow.otago.ac.nz (J.D.L. White); scott.bryan@yale.edu (S.E. Bryan); p_s_ross@hotmail.com (P-S. Ross); Stephen.Self@open.ac.uk (S. Self); thor.thordarson@ed.ac.uk (Th. Thordarson).

\begin{abstract}
Large igneous provinces (LIPs) form in both oceanic and continental settings by the emplacement and eruption of voluminous magmas ranging from basalt to rhyolite in composition. Continental basaltic LIPs are the best studied, and consist of crustal intrusive systems, extensive flood lavas and ignimbrites, and mafic volcaniclastic deposits in varying proportions. Intrusive rocks are inferred to represent the solidified remnants of a plumbing system that fed eruptions at the surface, as well as themselves representing substantial accumulations of magma in the subsurface. The vast majority of intrusive rock within the upper crust is in widespread sills, the emplacement of which may structurally isolate and dismember upper crustal strata from underlying basement, as well as spawning dike assemblages of complex geometry. Interaction of dikes and shoaling sills with near-surface aquifers is implicated in development of mafic volcaniclastic deposits which, in better-studed provinces, comprise large vent complexes and substantial primary volcaniclastic deposits. Flood lavas generally postdate and overlie mafic volcaniclastic deposits, and are emplaced as pahoehoe flows at a grand scale (up to $10^{4} \mathrm{~km}^{2}$ ) from eruptions lasting years to decades. As with modern Hawaiian analogues, pahoehoe flood lavas have erupted from fissure vents that sometimes show evidence for high lava fountains at times during eruption. In contrast to basaltic provinces, in which volcaniclastic deposits are significant but not dominant, silicic LIPs are dominated by deposits of explosive volcanism, although they also contain variably significant contributions from widespread lavas. Few vent sites have been identified for silicic eruptive units in LIPs, but it has been recognised that some ignimbrites have also been erupted from fissure-like vents. Although silicic LIPs are an important, albeit less common, expression of LIP events along continental margins, the large volumes of easily erodible primary volcaniclastic deposits result in these provinces also having a significant sedimentary signature in the geologic record. The inter-relationships between between flood basalt lavas and volcaniclastic deposits during LIP formation can provide
\end{abstract}


important constraints on the relative timings between LIP magmatism, extension, kilometre-scale uplift, and palaeoenvironmental changes.

\section{Introduction}

Large igneous provinces (LIPs) have been the subject of many previous papers and books, most with a petrological or geodynamic focus. The papers in this volume devoted to George Walker focus, in contrast, on physical processes of magmatism, and for LIPs a diversity of physical magmatic phenomena are known to be involved in their emplacement. George had an interest in the styles of lavas that form LIPs and his early work was influential - including his Deccan Traps-based paper that proposed compound vs. simple flows (Walker, 1969, 1972). In this article, we update and review aspects of physical volcanology for continental basaltic and silicic LIPs. For basaltic continental LIPs, we assess the hypabyssal magma distribution system for eruptions, the emplacement of extensive basaltic lava flows, and the extent and significance of mafic volcaniclastic deposits accompanying flood lavas. Silicic LIPs are dominated by pyroclastic deposits but in contrast to the basaltic examples, their plumbing systems are less wellexposed and studied. We conclude with a brief evaluation of the context for physical volcanological studies in LIPs, and a summary of key volcanological processes active during their emplacement.

\section{Magma Distribution Systems: Dikes and Sills of Continental LIPs}

Although the most prominent and longest studied rocks of continental large igneous provinces are thick stacks of basaltic lavas, the first section of this manuscript addresses the solidified lithospheric magma distribution systems that fed the lavas. These "plumbing systems" are represented by extensive sills and dikes, now exposed at different levels in variously eroded provinces (e.g. Richey, 1948; Ernst and Baragar, 1992; Tegner et al., 1998; Chevallier and Woodward, 1999; Elliot and Fleming, 2004). Giant dike swarms and other intrusions inferred to have been coupled with surface eruptions are exposed in deeply eroded continental provinces (Ernst and Baragar, 1992; Hatton and Schweizer, 1995; Ernst and Buchan, 1997, 2001; Ernst et al., 2005), whereas a range of intrusive complexes, sill networks and populations of smaller dikes are known from settings within a few km of the paleoeruption surface. 
Whatever the origin of LIP magmas, or the tectonic regime associated with their emplacement, the resulting intrusive rocks represent substantial volumes of unerupted magma (Crisp, 1984; Walker, 1993). The underplated igneous volume can be up to ten times larger than the associated extrusive volume. For example, in the North Atlantic Igneous Province, Roberts et al. (1984) estimated the total volume of Palaeocene to early Eocene basalt to be $2 \mathrm{Mkm}^{3}$, whereas White et al. (1987) and White \& McKenzie (1989) suggested a total volume of up to $10 \mathrm{Mkm}^{3}$, and Eldholm \& Grue (1994) estimated a total crustal volume of $6.6 \mathrm{Mkm}^{3}$.

Magma that solidified in sills, dikes and other intrusive complexes developed in host rocks as a result of mechanical coupling between magmatic pressure and the stress regime extant during their emplacement (Anderson, 1951; Rubin, 1995). Assuming that dike-sill orientations reflect deformation in homogeneous media at crustal or lithospheric scales, the geometries of the solidified magmatic plumbing networks have been used to infer stress regimes during emplacement, and to infer tectonic context and magma origin (Wilson, 1993; Head and Kreslavsky, 2002; Wilson and Head, 2002; Ernst and Desnoyers, 2004; Elliot and Fleming, 2004). The nature of magma transport at depth is not, however, readily determined in regions where only shallower exposure exists, as illustrated by the range of possibilities considered by Elliot and Fleming (2004) for delivery of magma to the Ferrar Group intrusions and flood basalts in Antarctica (Figure 1). This uncertainty makes it more challenging to determine the ultimate sources of magma for various LIPs, whether it is generated in linear zones below eruption fissures or distributed along such zones over large distances from a central source (e.g., MacKenzie dyke swarm; Baragar et al., 1996).

Given the dynamics of magma intrusion and structural decoupling of strata buoyed above extensive sills, it may not be valid to assume that dike-sill orientations can be used directly to infer regional tectonic stresses. This may be particularly relevant for LIPs characterised by widespread and voluminous sills, such as the Karoo Dolerite of southern Africa (Figure 2) and its spectacularly exposed Antarctic counterpart, the Ferrar Dolerite. Consider the enormous Peneplain Sill in the Dry Valleys, Antarctica, $\left(19,000 \mathrm{~km}^{2}, 1 / 4 \mathrm{~km}\right.$ thick), which was intruded beneath $\sim 2 \mathrm{~km}$ of sedimentary rock (Gunn and Warren, 1962). Had the sill been intruded "instantaneously", the overlying sedimentary rock would have been decoupled from underlying 
basement rock by a liquid-plastic layer of magma; the lid would have been isolated from any tectonic stress exerted on the rocks below. Emplacement is not instantaneous, but sills maintain deformable interiors during emplacement (Marsh, 1996), which limits mechanical coupling through them (Hawkesworth et al., 2000; Marsh, 2004). Also, sills grow by fluid-dynamic insertion of magma which, under triaxial stress regimes and into homogeneous or simply layered host rocks produces saucer-shaped or stepped-saucer sills (Chevallier and Woodford, 1999; Malthe-Sørenssen et al, 2004). As a sill spreads from a magma supply site, the rock above is progressively wedged and buoyed upward (Chevallier and Woodward, 1999; Thomson and Hutton, 2004). This process transmits stress through the uplifting rock, and cracks thus created are filled by magma to produce dikes (Pollard and Johnson, 1973; White et al., 2005). Dikes spawned in this way reflect near-field stresses from the intrusion process itself, rather than farfield tectonic stresses affecting the crust below the sill.

In South Victoria Land, Antarctica, many Ferrar intrusions change their shape and orientation along their length; horizontal sills locally feed into subvertical dikes, dikes change strike abruptly, and the form of the fractures occupied by magma varies widely across small areas (Elliot and Fleming, 2004). Outcrops at Mount Gran and Terra Cotta Mountain (Figure 3) illustrate this complexity at paleodepths of $\sim 1-2.5 \mathrm{~km}$, which is somewhat unexpected, because magma transport at such depths has been treated as being controlled predominantly by the regional stress field.

Terra Cotta Mountain exposes rocks from $\sim 1-2 \mathrm{~km}$ below the surface, including a sill separating basement from sedimentary cover rocks, a large "mega"dike, and swarms of subparallel to suborthogonal inclined sheets of varying thickness. Higher in the overall sequence, a spectacular cliff at Mount Gran similary exposes a megadike at the local terminus of a thick sill, with the megadike apparently feeding a splay of inclined sheets (Figure 3b). At both sites, significant displacements of country rock take place across thick dikes, at least partly in response to differential jacking-up of strata by sills that terminate at these dikes.

The rather chaotic pattern seen at both Mt Gran and Terra Cotta Mtn is more consistent with country rock acting as a 'floated' lid on top of, or partly within, a fluid magma, with cracks 
forming in response to very local stresses rather than regional ones (White et al., 2005). This conclusion gains additional support from the contact geometries of some dikes, which show irregular buds and extensions that indicate different directions of magma flow and/or of dike propagation among closely-spaced dikes. Local regularities in dike-set geometries may reflect intrusion dynamics, with wedging and uplift during initial sill propagation causing systematic cracking of the floated lid. Other dike-set patterns may result from inhomogeneities in the country rock caused by jointing, fracturing, faulting or folding, interlayering of rock units with contrasting rheologies, or the presence of older intrusive rocks.

At Coombs Hills, Ferrar Dolerite outcrops extend to within $200 \mathrm{~m}$ of the base of nearby flood lavas adjacent to the Coombs Hills vent complex (Ross et al., 2008). At this level, large domains of country rock are isolated and tilted within dolerite bodies (Figure 4a), and the country rock domains are additionally cut in complex patterns (Figure $4 \mathrm{~b}$ ) by both wedge-shaped, and small, commonly sinuous, dikes (White and Garland, 2007). It appears that as Ferrar sills approached the ground surface at Coombs Hills, at least a hundred metres of overlying country rock was broken into blocks that became separated from one another, commonly rotated, and partly to wholly engulfed in incrementally inflated doleritic sills. An absence among the large tilted blocks of flood-basalt lavas suggests that at Coombs Hills the process predated emplacement of overlying flood basalts (White et al., 2006). Such wholesale breakup of country rock at shallow intrusion levels may well be related to development of vent complexes such as that at Coombs Hills, but the nature of this relationship remains to be determined.

Extensive dyke swarms are exposed in the more deeply eroded silicic LIPs (e.g., Whitsunday, Kennedy-Connors-Auburn; Ewart et al., 1992; Stephenson et al., 1990; Bryan, 2007). Diffuse swarms ( $\geq 100 \mathrm{~km}$ wide) of mostly steeply-dipping dykes ranging between 1-50 $\mathrm{m}$ in width are characteristic, and the swarms can extend along strike for over $1000 \mathrm{~km}$ (Stephenson et al., 1990). Silicic LIPs may have similarly extensive mid- to upper-crustal granitic batholith underpinnings and dyke swarms, and more-mafic igneous underplate at lower crustal depths (Ferrari et al., 2007), but our understanding of the magma plumbing systems of silicic LIPs remains limited in comparison to what is known for CFBPs. 
In summary, the final emplacement of substantial volumes of magma generated in continental LIPs may be at relatively shallow depths (upper few $\mathrm{km}$ ). The geometry and emplacement processes of these intrusions are controlled by the interaction between magma fluid dynamics and tectonic stresses. As large intrusions approach the ground surface, overlying rocks can be broken apart and effectively engulfed within them.

\section{Lava flows in continental flood basalt provinces}

In less-eroded continental flood basalt provinces (CFBPs), very thick piles of basaltic lava flows (more than $3 \mathrm{~km}$ thick in some cases) are seen to make up the bulk of each province. Although they have been studied since the inception of geology as a science (see Walker 1995 for a review), the flows are so extensive, and the flood basalt provinces so widespread and generally broken up by rifting, that it has taken much painstaking work to piece together a picture of the 'typical' product of a flood basalt eruption. The most valuable work so far for flood basalt interpretation has been based upon the Columbia River Basalt province, the smallest, youngest, and arguably the most intact, CFBP. Decades of effort by many workers, summarised in papers such as Tolan et al. (1989) and Reidel et al. (1989) in Reidel and Hooper (1989), show that individual flow fields, each the product of a single eruption, are huge in volume, commonly exceeding $1,000 \mathrm{~km}^{3}$ of lava. Furthermore, volcanological studies show that these eruptions were fed by very long fissures (e.g., Swanson et al., 1975) and that at least parts of the eruptions were Hawaiian-like in nature at the vent (Reidel and Tolan, 1992), featuring small lava ponds.

\section{Lava flow fields}

The lava piles in CFBPs are composed of flow fields almost always of pahoehoe or rubbly pahoehoe (as in more-modern lava fields, Guilbaud et al., 2005), with the latter forming up to $30 \%$ of flows in some provinces (Keszthelyi et al., 2002; 2004). The flow fields have been proposed to have originated from prolonged eruptions that probably lasted for years to decades (Self et al., 1996, 1997, 1998; Thordarson and Self, 1996, 1998). Each flow field consists of several major lava flows, which in turn consist of multiple flow lobes. The number of individual lava bodies within one flow field must be very large indeed. The major sheet lobes, containing the majority of the lava volume, are commonly 20 to $30 \mathrm{~m}$ thick, several kilometres wide, and show features consistent with in situ flow thickening by inflation (endogenous growth; Figure 5). 
These extensive lobes, with aspect ratios (length/thickness) ranging from $\sim 50$ to $\sim 500$, are the basic building-blocks of a CFBP and give the provinces their "layer-cake" or, when eroded, steplike, appearance. The similarity of processes that form sheet lobes within any CFBP gives a consistent internal structure to the lava units that is typified by the schematic section shown on Figure 6. Lava units are usually pipe-vesicle-bearing pahoehoe lavas (Figure 7), and the often complexely jointed vesicular upper crustal zone can occupy $40-60 \%$ of the sheet lobe thickness.

The morphology of the lava bodies, their surface characteristics, and internal textures appear to change little from vent to toe in flood basalt flow fields, which can extend over distances in excess of 500, or even 1000, kilometres (Hooper, 1996; Self et al., 2008). Proximal lava flows tend to be thinner than the thick sheet lobes that occupy the almost infinitely low slopes of the main parts of a province. Sheet lobe refers to a single flow lobe that is a large-scale feature, i.e., wider than an outcrop, and 10s of metres thick, as is common in CFBPs, This same basic volcanic architecture has been reported from each flood basalt province where physical descriptions of the lavas have been made, including the Kerguelen plateau (Keszthelyi, 2002), Etendeka (Jerram, 2000), North Atlantic Igneous Province (Single and Jerram, 2004) and Deccan (Bondre et al., 2004; see review by Jerram and Widdowson (2005). A common variant is flows with pahoehoe bases and internal structures capped by a rubbly top often over $10 \mathrm{~m}$ in thickness. These so-called rubbly pahoehoe lava units have been described from smaller, more recent flood lava flow-fields (Laki, Iceland; Guilbaud et al, 2005) and CFBPs (Kerguelen, Columbia River Basalts, see references above), and some slabby-topped flows have been described from the Deccan province (Duraiswami et al., 2003).

Both geothermometry and thermal modeling of Columbia River lava flows show that the great extent of individual lava flows was not limited by cooling (Keszthelyi et al., 2004). The insulated transport of lava under a thick crust is thermally extremely efficient, with measured cooling rates of $<<0.1{ }^{\circ} \mathrm{C}$ per km flowed (Ho and Cashman, 1997; Thordarson and Self, 1998). Theoretically, this mode of emplacement can produce lava flows $>1000 \mathrm{~km}$ long with modest lava fluxes (Self et al., 2008). In a study of long Quaternary basaltic lava flows (>100 km long) of the McBride province in northern Australia, it was concluded that lava flows $>10$ 's km were favoured by a pahoehoe emplacement style (thermal insulation), sustained eruption over years to 
tens of years, favourable slopes, unhindered flow conditions (e.g., dry river beds) and an insulated conduit system (lava tubes), but that lava flow size was ultimately limited by supply (Stephenson et al., 1998). Thus the key to these "floods" of lava is the immense volume of magma released during one eruption, rather than the lava viscosity, eruption rate, or environmental conditions (Keszthelyi and Self, 1998). Recent studies of lavas in the Deccan Traps show that inflated pahoehoe lavas are common in that province, with the implication that insulated transport also played an important role their emplacement (e.g. Keszthelyi et al., 1999: Duraiswami et al., 2002, 2003; Bondre et al., 2004; Jay, 2005). Many details are still not available, however, and different CFBPs may have distinct lava characteristics (Bondre et al., 2004).

\section{Flood basalt vents}

Important additional information about the nature of flood basalt eruptions can be gleaned from the nature of the vents, although the number of reports of vent facies from CFBPs is very small. This partly reflects that fact that the vent systems are small, often-linear components in huge lava provinces, so there is low probability that they will be commonly exposed. Moreover, in many CFBPs rifting may occur along the trends of earlier fissure-vent systems, perhaps preferentially destroying evidence of the vent regions (Hooper, 1990). The occurrence of dike systems that can be traced laterally for $10 \mathrm{~s}-100 \mathrm{~s} \mathrm{~km}$ imply that many flood basalt eruptions are fed from linear vent systems. The fissures appear to cluster in time and space, such that one lava formation within a CFBP is often erupted from a group of sub-parallel linear-vent systems, represented by dyke groupings (Hooper, 1990; Walker, 1995). The best documented examples of the apparently rarely outcropping surface-vent constructs and vent successions are found within the Columbia River Basalts (Swanson et al., 1975), where associations of fountain-fed flows, spatter and lapilli scoria units, and spongy and shelly pahoehoe lobes appear to define complex linear vent systems that bear a resemblance to the cone complexes formed by modern-day fissure eruptions. One indepth study of a vent structure within the $\sim 16$ Ma Teepee Butte Member of the Grande Ronde basalts shows that it featured a lava pond surrounded by cone ramparts that were constructed by at least three distinct episodes of Hawaiian-style fountaining (Reidel and Tolan, 1992). An important consideration is that evidence preserved around basaltic vents may represent processes occurring in the dying stages of vents and fissure segments, and not what was occurring during 
the periods of maximum effusion rate.

The near-vent succession of the 14.7 Ma Roza Member is a sequence of fountain-fed lava flows overlain by 1- to 10-m-thick bedded lapilli scoria units, which in turn are capped by either fountain-fed lava or pahoehoe sheet lobes (Thordarson, 1995; Thordarson and Self, 1996). The scoria units are of particular interest as they consist of uniform fine to medium lapilli scoria and exhibit a near-horizontal internal bedding. This sequence of fountain-fed lavas, scoria beds, and "normal" lavas is identical to that found in the near-vent successions of the 1783-84 AD Laki and 934-40 AD Eldgjá fissure-fed flood lava eruptions (Figure 8a), where each sequence is the product of one eruption episode. The resemblance is also enhanced by the similar grain-size distributions and clast morphologies in these deposits to those found in flood basalt provinces. In the historic eruptions, the scoria units were produced by sub-Plinian explosive phases at the beginnings of individual eruption episodes because, at the onset of degassing, the exsolved volatiles streamed up through the magma column to form a two-phase flow in the upper part of the conduit. This resulted in gas-driven explosive eruptions at the surface that produced the early fountain-fed flows. Because of this initial bulk loss of volatiles the conduit flow was converted to the bubbly flow regime and the style of the eruption changed to weak fountaining and effusion of normal lava. This pattern then repeated in the subsequent eruption episodes. Although the tephra falls produced by the explosive phases in flood basalt volcanism are minor components compared to the volume of lava erupted, the significance of these phases for assessing eruption dynamics and possible atmospheric effects should not be underestimated (Self et al., 2005). They record periods of peak magma discharge that produced eruptions of sub-Plinian intensities.

The picture that is emerging conforms well with the notion that these fissure-fed lava-producing events are large-scale versions of the historic flood lava eruptions in Iceland. Thus by analogy, it is likely that flood basalt eruptions featured multiple episodes, each beginning with a relatively short-lived explosive phase followed by a longer-lasting effusive phase. After fissure activity, effusion may have settled down to one of a few points along the linear vent system, and small shields (and cones; Figure 8b) are known along the Roza fissure of the Columbia River province (Swanson et al., 1975). Another important conclusion that can be drawn from this comparison is that it is unlikely that the entire vent system erupted concurrently. It is more likely that at any 
one time the activity was confined to distinct fissure segments on the vent system, as indicated by mapping of the Roza lava flow field (Thordarson and Self, 1998). The lava flow-fields also grew incrementally, with active lava emplacement in only one part, or a few parts, of the whole field at any one time. It should be noted that ten years of effusion at the maximum sustained Laki eruption rate (estimated at $\sim 4000 \mathrm{~m}^{3} \mathrm{~s}^{-1}$; Thordarson and Self, 1993) would yield a 'flood-basaltmagnitude' flow field $\left(\sim 1250 \mathrm{~km}^{3}\right.$ We also note that the Laki-flow field has been shown to contain abundant lava tubes in the proximal to medial regions (Wood and Watts, 2002), and can be considered, in current state of knowledge, largely a tube-fed lava field.

\section{Volcaniclastic rocks in LIPS}

Not all the eruptions of LIPs were predominantly effusive. A range of volcaniclastic deposits, in addition to the informative but relatively small-volume tephra falls of sub-Plinian eruptions mentioned above, are found. The various volcaniclastic deposits contain information on erupted magma compositions, primary fragmentation mechanisms, eruptive processes, depositional environments and tectonomagmatic evolution. This section reviews the main characteristics and proposed origins of volcaniclastic rocks associated with LIPs.

We follow White and Houghton (2006) in defining primary volcaniclastic deposits and rocks as "the entire range of fragmental products deposited directly, by explosive or effusive eruption". In this classification, "primary volcaniclastic" replaces the broadest use of "pyroclastic" in Fisher and Schmincke (1984) as the core term for the family of particles and deposits formed by volcanic eruptions. Primary volcaniclastic deposits may include older fragments ejected or moved during an eruption. Reworked volcaniclastic deposits refer to those comprising particles that have been derived from primary volcaniclastic deposits, and redeposited by surface processes (e.g., wind, rivers, non-eruptive density currents, ocean currents), either during an eruption or after a storage period (syn-eruptive resedimented volcaniclastic deposits of McPhie et al., 1993). Epiclastic deposits or volcanogenic sedimentary rocks (McPhie et al., 1993) are those produced by weathering and erosion of volcanic (including lithified volcaniclastic) rocks, and their rates of production are hence controlled largely by weathering. White and Houghton (2006) recognised four end-member groups of primary volcaniclastic deposits: 1) pyroclastic deposits from pyroclastic plumes and jets or pyroclastic density currents; 2) autoclastic deposits formed 
when effusing magma cools by contact with air and the fragments produced accumulate to produce in situ deposits; 3) hyaloclastic deposits (hyaloclastite) and pillow breccia formed when magma effuses subaqueously, is quenched in contact with water, and produces fragments accumulated as in situ deposits, and; 4) peperite, formed during shallow intrusion of magma into a clastic host; fragments of magma or lava form by mingling with the debris (typically wet), with deposition effectively in situ (e.g., White et al., 2000).

Pyroclastic deposits thus defined may comprise fragments produced by both phreatomagmatic and magmatic fragmentation processes. We therefore use 'magmatic' fragmentation (e.g. Houghton and Wilson, 1989) to describe fragmentation occurring within the conduit due to gas expansion and/or magma shear, without the influence of external water.

\section{Mafic volcaniclastic rocks in LIPs}

Kilometre-thick piles of basaltic lava are not only characteristic of continental flood basalt provinces but also characterise other LIP-types such as volcanic passive margins and oceanic plateaus (e.g., Coffin and Eldhom, 1994; Menzies et al., 2002; Kerr, 2003; Kerr \& Mahoney, 2007). Volcaniclastic deposits constitute significant stratigraphic thicknesses and volumes of several mafic LIPs (Bryan et al., 2002; Ross et al., 2005; Ukstins Peate et al., 2005), but are reportedly sparse for others (e.g., Columbia River, Deccan), or have been misinterpreted (e.g, as epiclastic alluvial fan deposits in the Emeishan flood basalt province, He et al., 2003). Mafic volcaniclastic deposits have been a relatively neglected research topic thus far, despite their implications for palaeoenvironmental reconstructions, magma production and supply rates, eruption dynamics, and climatic impacts.

Mafic volcaniclastic deposits, now mostly lithified, exist in various proportions in most Phanerozoic CFBPs (Table 1), as well as in some Precambrian examples (Blake, 2001) and in silicic LIPs (Pankhurst et al., 1998; Bryan et al., 2000). Several hundred metres of mafic volcaniclastic deposits have also been found in one drill hole from the Ontong Java Plateau, a largely submarine LIP (Shipboard Scientific Party, 2001; Thordarson, 2004). Salient points, in part drawn from the review paper by Ross et al. (2005), include the following. 
- Mafic volcaniclastic deposits occur principally as intercalated horizons among lava flows in some flood basalt provinces (e.g., Vøring Plateau in the North Atlantic; Noril'sk area on Siberian platform; Deccan plateau), whereas in others they are concentrated in the lower part of the volcanic stratigraphy (e.g., East Greenland; Emeishan; Ferrar; Karoo; Tunguska basin on Siberian platform); in the latter cases, clastic accumulations can reach hundreds of metres in thickness (Figure 9). In the silicic LIPs, mafic volcaniclastic rocks generally occur in the upper parts of the eruptive stratigraphy (Figure 12) following short-lived, large volume pulses of silicic ignimbrite volcanism (e.g., Whitsunday, Sierra Madre Occidental).

- The known areal extent of mafic volcaniclastic deposits ranges from quite restricted (e.g., the vent-proximal pyroclastic accumulations on the Columbia River plateau) to hundreds of thousands of square kilometres (Siberian platform, Figure 10);

- In many provinces, the deposits include abundant coarse lapilli-tuffs and tuff-breccias of mostly phreatomagmatic origin (e.g., East Greenland, Ferrar, Karoo, Emeishan), and are presumably exposed close to the source vents (Figure 11);

- Particles forming the volcaniclastic deposits were distributed by a range of processes including pyroclastic density currents (Ross and White, 2005a), vent- or conduit-confined debris jets (White and McClintock, 2001; Ross and White, 2006; McClintock and White, 2006), fall from volcanic plumes, mass flows (e.g. Hanson and Elliot, 1986), and stream flows (e.g. McClintock et al., 2008).

- Mafic volcanism in the silicic LIPs has produced the same volcanic structures as modern basaltic intraplate (largely monogenetic) volcanic fields such as the Newer Volcanics Province (Johnson, 1989) and Auckland Volcanic Field (Johnson, 1989; Houghton et al., 1999).

Mafic volcaniclastic deposits produced as a result of magmatic fragmentation are generally of limited volume in LIPs, and those of the Columbia River Basalts described previously are typical. It is inferred that fire fountaining was relatively common at vent sites for mafic flood lavas (Thordarson and Self, 1996), but in many cases, the very hot pyroclasts (lava clots, spatter) coalesced upon landing to form clastogenic lava feeding into extensive flow fields. The original volume of basalt that underwent magmatic fragmentation during Columbia River (and other 
mafic LIP) eruptions was probably greater than that preserved in the geologic record, because coalescence processes convert fountain pyroclasts to lava, and because pyroclastic deposits are locally eroded by lava-flow "bulldozing" (as seen during modern eruptions in Hawaii; Swanson et al., 1975). Rare, weakly-welded pyroclastic deposits composed of degassed basalt fragments with few lithics have been described from the Karoo (McClintock et al., 2008), but the style of magmatic eruption that produced them remains incompletely understood.

Much larger volumes of preserved mafic volcaniclastic deposits are attributed to magma-water interaction, i.e. quench-induced hyaloclastic and explosive phreatomagmatic fragmentation (Ross et al., 2005). In the East Greenland, Ferrar, Karoo and Emeishan provinces, coarse phreatomagmatic lapilli-tuffs and tuff-breccias are composed of dense to poorly vesicular blocky sideromelane (or altered basaltic glass) clasts mixed with country rock fragments, or in some cases, loose quartz particles derived from sandstones (Hanson and Elliot, 1996; Elliot and Hanson, 2001; Ukstins Peate et al., 2003a; McClintock and White, 2006). Limestone-bearing mafic volcaniclastic rocks toward the base of the Emeishan province reflect explosive interaction between flood basalt magmas and a carbonate reef platform. Basaltic accretionary lapilli tuffs, found in several provinces (North Atlantic, Ontong Java Plateau, Ferrar, Karoo, Emeishan) are commonly associated with phreatomagmatic eruptions and indicate the generation of subaerial plumes. Mafic phreatomagmatic activity in some silicic LIPs where lakes were present locally produced vent-proximal accumulations (10's to 100's of m thickness) of basaltic base surge deposits and/or accretionary lapilli-bearing tuff rings or cones. Mafic phreatomagmatism in silicic LIPs appears to be far less significant than in the CFBPs, no doubt attributable in part to the much smaller volumes of mafic magma erupted.

Where abundant surface water is present on continents or when lava enters the sea, mafic lava flows generally experience quenching and spalling; typical products include pillow lavas, pillowpalagonite breccias, and hyaloclastite. Pillow-palagonite complexes are common at the base of basalt flows in parts of the Columbia River Plateau (Swanson and Wright, 1981; Hooper, 1997), and are present in rift basins (e.g., Hartford Basin) of the Central Atlantic Magmatic Province. Pillow lavas are also present in the Karoo succession (McClintock et al., 2008), in lower and central sections of the Emeishan flood basalt province (Binchuan section of Xu et al., 2004), and 
at the base of the Mull lava succession in the North Atlantic Igneous Province (Kerr, 1995). Hyaloclastite piles are documented onshore in East Greenland (Nielsen et al., 1981) and mafic volcaniclastic deposits may be important in syn- to post-rift sequences along volcanic rifted margins (Planke et al., 2000). A hyaloclastite complex is also documented from an Archean LIP in the eastern Pilbara Craton of Western Australia (Blake, 2001). Pillowed lavas and peperitic intrusions have also been reported, formed in marine or, more commonly, lacustrine environments (Pankhurst et al., 1998; Bryan et al., 2000).

Autoclastic fragmentation of mafic lavas generates breccias (e.g., a'a' clinker, slabby and rubbly pahoehoe). Interaction of lavas with aeolian sand formed peperitic rocks in the arid landscape in which the Etendeka LIP was emplaced (Jerram and Stollhofen, 2002). Other peperites associated with mafic LIPs clearly formed in the presence of water, as where the Pomona Basalt invaded water-saturated silicic ash of the Ellensburg Formation to form peperites exposed over an area of about $5400 \mathrm{~km}^{2}$ in south-central Washington (Schmincke, 1967). Peperites are also known from inside the vents of mostly phreatomagmatic mafic volcaniclastic deposits, where wet fragmental material was in abundant supply (McClintock and White, 2002; Ross, 2005).

Reworked mafic volcaniclastic deposits are known from East Greenland (Heister et al., 2001; Ukstins Peate et al., 2003a), the North Sea (phase 1 ashes, Knox and Morton, 1988), the Ferrar (Carapace Sandstone, see Ross et al., 2008) and the Karoo (Ross et al., 2005; McClintock et al., 2008). Reworked deposits are a natural accompaniment, in variable proportions, to primary mafic volcaniclastic deposits wherever they are found.

\section{Silicic Volcaniclastic rocks and lavas in LIPs}

Silicic volcaniclastic rocks have long been recognised within LIPs otherwise dominated by flood basaltic lavas and ranging in age from Precambrian (e.g., Twist and French, 1983; Thorne and Trendall, 2001; Blake et al., 2004) to Cenozoic. Detailed descriptions are relatively limited in the literature (see review in Bryan et al., 2002), and our knowledge of the scale and magnitude of silicic eruptions from CFBPs has been greatly improved by the detailed studies on silicic volcanic units in the Paraná-Etendeka (Milner, 1988; Milner et al., 1992; 1995; Bellieni et al., 1986; Garland, 1994; Garland et al., 1995; Ewart et al., 1998, 2004), and most recently, the 
Afro-Arabian flood volcanic provinces (Baker et al., 1996; Ukstins Peate, et al., 2003b, 2005).

Silicic LIPs represent the largest accumulations of volcaniclastic rocks on Earth and have dimensions comparable to those of CFBPs (Bryan et al., 2002; Bryan, 2007; Bryan \& Ernst, 2008). Like their better-known CFBP counterparts, silicic LIPs bear all the hallmarks of LIP events, in particular, large erupted volumes $\left(>0.25 \mathrm{Mkm}^{3}\right)$ and areal extents $\left(>0.1 \mathrm{Mkm}^{2}\right)$, evidence for very high magma-emplacment rates over short periods, and intraplate tectonic settings or geochemical affinities (Bryan, 2007; Bryan \& Ernst, 2008). Ignimbrite-dominated silicic LIPs of Late Paleozoic to Cenozoic age are the best preserved, and represented by the Early Cretaceous Whitsunday Igneous Province of eastern Australia (Ewart et al., 1992; Bryan et al., 1997, 2000), the Jurassic Chon Aike Province of South America-Antarctica (e.g., Pankhurst et al., 1998, 2000; Riley and Leat, 1999); the middle Tertiary Sierra Madre Occidental Province of Mexico (e.g., McDowell and Clabaugh, 1979; Swanson and McDowell, 1984; Ferrari et al., 2002), and the Permo-Carboniferous Kennedy-Connors-Auburn Igneous Province of eastern Australia (Bain and Draper, 1997; Bryan et al., 2003). The Whitsunday and Chon Aike provinces were spatially and temporally related to emplacement of other LIPs and episodes of continental break-up. Proterozoic examples have significantly smaller preserved volumes $\left(1 \times 10^{5} \mathrm{~km}^{3}\right)$, and may include the $\sim 750 \mathrm{Ma}$ Malani (India; Sharma, 2005) and the $\sim 1590 \mathrm{Ma}$ Gawler Range-Hiltaba (South Australia; Daly et al., 1998; Allen et al., 2003) igneous provinces.

The Sierra Madre Occidental province of Mexico, being the best preserved example of a silicic LIP, is representative of their general architecture. It is an extensive, relatively flat-lying ignimbrite plateau covering from $10^{5}$ to $10^{6} \mathrm{~km}^{2}$ (2000 km long and 200 to $500 \mathrm{~km}$ wide) to an average thickness of $1 \mathrm{~km}$ (e.g., McDowell and Clabaugh, 1979; Ferrari et al., 2002). Sierra Madre Occidental volcanism was concurrent with the widespread "ignimbrite flare-up" in the Basin \& Range Province of western U.S.A. where an additional $10^{5} \mathrm{~km}^{3}$ of dacitic to rhyolitic ignimbrite was emplaced between $\sim 35$ and $20 \mathrm{Ma}$, but which has now largely been dismembered by basin and range extension (Lipman et al., 1972; Gans et al., 1989; Best and Christiansen, 1991; Johnson, 1991; Axen et al., 1993; Ward, 1995). In general, the combination of burial, tilting, faulting, and exhumation have hindered mapping and volume estimation of individual ignimbrite eruptive units in LIPs. As an example, $<10 \%$ of the youngest and least deformed 
Sierra Madre Occidental province has so far been mapped (Swanson and McDowell, 2000; Swanson et al., 2006); an important item on the "future research" agenda is to improve the database on large-volume silicic provinces (see also Mason et al., 2004).

Even compared to flood-basaltic lava flows, silicic volcaniclastic deposits may be emplaced over vast areas ( $\sim 2 \%$ of the globe for Toba, Rose \& Chesner, 1987), and may also have eruptive volumes (e.g., Mason et al., 2004) that equal or exceed those of the largest mafic lava flows. The large eruptive fluxes and upper-atmospheric effects of silicic eruptions may combine with effects of flood basalt eruptions to force environmental and climatic changes during LIP emplacement, so it is important to understand their timing relative to, and petrogenetic relationships with, roughly coeval flood basalts. In the CFBPs, the silicic pyroclastic deposits are also of great stratigraphic utility, forming laterally continuous and distinctive marker horizons that constrain volcanic stratigraphies over several hundreds of kms within often monotonous and internally complex flood basalt lava successions (Jerram, 2002; Bryan et al., 2002; Ukstins Peate et al., 2005). For example, large-volume silicic units have proved vitally important in establishing stratigraphic correlations between the Paraná and Etendeka flood basalt provinces, which are now separated by the South Atlantic Ocean (Milner et al., 1995). Silicic volcanic and volcaniclastic rocks can represent a significant contribution to the total magmatic output of CFBPs (5-10 volume\%; e.g., Paraná-Etendeka; Afro-Arabian). The size of some individual Paraná-Etendeka silicic units is truly impressive, with the largest covering areas $>100,000 \mathrm{~km}^{2}$ and representing erupted volumes of $c a .5,000 \mathrm{~km}^{3}$ dense rock equivalent; they are amongst the largest volume eruptive units so far recognised on Earth (Milner et al., 1995; Marsh et al., 2001; Ewart et al., 1998, 2004; Mason et al., 2004).

Pyroclastic rocks, primarily ignimbrites (pyroclastic-density-current deposits) are the dominant products of silicic volcanism within CFBPs, silicic LIPs and along volcanic passive margins. This is particularly the case for those CFBPs having large volumes of silicic deposits $\left(>10^{3} \mathrm{~km}^{3}\right.$; Bryan et al., 2002). Ignimbrite typically represents $>75 \%$ of the total stratigraphic thickness (generally $>1 \mathrm{~km}$; Figure 12) of silicic LIPs, and multiple units can cover areas in excess of $5 \mathrm{x}$ $10^{5} \mathrm{~km}^{2}$. Thinner intervals of silicic tuffs or bentonites and breccias have been reported from oceanic plateaux (e.g., Northwest Australian margin, von Rad and Thurow, 1992; Caribbean- 
Colombian oceanic plateau; Kerr et al., 2004), and submerged syn- to post-rift sequences along continental margins (e.g., Larsen et al., 2003). Most recently, deep-sea ash layers thousands of kilometres from source have been correlated to onshore deposits of silicic explosive volcanism in the Afro-Arabian flood basalt province (Ukstins Peate et al., 2003b; Touchard et al., 2003a, b), with one major consequence being to dramatically increase the known volumes of silicic magma erupted in this province (Ukstins Peate et al., 2005; 2007). This result suggests that the volumetric significance of silicic volcanism in mafic LIPs, inferred for most provinces only from onshore records, is likely to have been greatly underestimated.

Ignimbrites in LIPs are dominantly dacitic to rhyolitic welded units that range from tens to a few hundreds of metres in thickness, and posess tabular geometries with moderate to low aspect ratios reflecting lateral extents of up to hundreds of kilometres, and dense rock equivalent volumes $>10^{3} \mathrm{~km}^{3}$ (e.g., McDowell and Clabaugh, 1979; Milner et al., 1995; Pankhurst et al., 1998; Bryan et al., 2000; Ukstins Peate et al., 2005). Intracaldera facies ignimbrite units $>1 \mathrm{~km}$ thick have been reported from the silicic LIPs, and are commonly associated with coarse lithic lag breccias (e.g., Ewart et al., 1992; Pankhurst et al., 1998; Bryan et al., 2000; Swanson et al., 2006). In detail, ignimbrites within and from different silicic LIPs show considerable variety in deposit features, such as welding intensity, and crystal, lithic and pumice contents. Rheomorphic ignimbrites are rare in silicic LIPs, reflecting generally low eruptive temperatures $\left(750-900^{\circ} \mathrm{C}\right.$; Cameron et al., 1980; Ewart et al., 1992; Wark, 1991). In contrast, many silicic eruptive units in the CFBPs are lava-like in character, particularly those in the Paraná Etendeka and Karoo provinces (e.g., Cleverly, 1979; Milner et al., 1992). The preferred interpretation has been that these units formed as rheoignimbrites or extremely high-grade ignimbrites (Branney \& Kokelaar, 1992; see also Walker, 1983) that erupted with relatively low explosivity at high eruptive temperatures $\left(>1000^{\circ} \mathrm{C}\right)$ and low magma viscosities $\left(10^{4} \mathrm{~Pa} \mathrm{~s}\right)$. Pyroclasts apparently maintained high temperatures to the sites of deposition, resulting in agglutination/coalescence and rheomorphism (Milner et al., 1992; Bryan et al., 2002). New studies of the quartz latites in the Etendeka province (Mawby et al., 2006) have recognised that the lava-like units exhibit the classic valley-fill geometry of ignimbrites, and in contrast to long silicic lava flows, do not possess basal or upper autobreccias along their strike length. Many other examples of ignimbrites in mafic LIPs have unequivocal pyroclastic textures, inferred eruptive temperatures 
$<1000^{\circ} \mathrm{C}$ (e.g., Kirstein et al., 2000; Ukstins Peate et al., 2005), and are potentially the products of eruptions that generated higher atmospheric plumes. This is confirmed by the correlation of such ignimbrites with distal ash fall deposits located thousands of kilometres from source (Ukstins Peate et al., 2003b; Touchard et al., 2003a,b).

Silicic phreatomagmatic deposits are relatively common in silicic LIPs, occurring as locally thick sequences of base surge deposits and/or accretionary lapilli tuff (e.g., Bryan et al., 2000), with several examples formed during early phases of ignimbrite-forming eruptions. Some accretionary lapilli have been interpreted to occur in deposits of co-ignimbrite ash clouds (Riley and Leat, 1999). In general, the phreatomagmatic deposits are fine-grained and lithic-poor, reflecting a highly efficient fragmentation process inferred to result from explosive interaction of magma with surface water. Sites of explosive magma-water interaction were lakes within rift valleys or flooded calderas, with the latter analogous to the eruptive environments that have characterised silicic explosive eruptions in the Taupo Volcanic Zone (e.g., Wilson et al., 1995). Quench fragmented silicic lava is common where lavas were extruded onto the floors of flooded calderas.

Rhyolitic lavas and associated autoclastic facies are present in continental LIPs, but are clearly subordinate in volume to silicic pyroclastic rocks. Lavas appear to be more volumetrically significant, however, in Precambrian provinces (e.g., Bushveld, Twist and French, 1983; Mesoproterozoic Gawler Range Volcanics, Allen and McPhie, 2002; Allen et al., 2003), and where the total volume of silicic volcanics in a LIP is low $\left(<10^{3} \mathrm{~km}^{3 ;}\right.$; e.g., Deccan - Lightfoot et al., 1987).

As recognised following recent caldera-forming (26.5 ka Oruanui; Manville \& Wilson, 2004; Taupo 1800a, Manville et al., 2005) and small-volume historical eruptions (e.g., Mount St. Helens, Major et al., 2000; Pinatubo, Newhall and Punongbayan, 1996), the remobilisation and redeposition of unconsolidated pyroclastic material by fluvial and mass-flow processes can be extensive and protracted, affecting large areas otherwise untouched by the eruption. Similarly, substantial remobilisation and reworking of silicic volcaniclastic material has occurred during eruptive hiatuses in the emplacement of LIPs, resulting in reworked volcaniclastic deposits. Resedimented volcaniclastic deposits are volumetrically larger in silicic LIPs than in CFBPs, 
reflecting the greater abundance of pyroclastic debris (nonwelded ignimbrites, fall and surge deposits) available for reworking. Substantial volumes of reworked volcaniclastic rocks are associated with the Whitsunday silicic LIP in eastern Australia (Bryan et al., 1997), which was the source of $>1.4 \times 10^{6} \mathrm{~km}^{3}$ of predominantly sand-sized volcaniclastic sediment that was rapidly generated and transported over large distances with limited weathering (Smart and Senior, 1980), fundamentally altering the basin-fill history of at least two major continental sedimentary basin systems (Bryan et al., 1997).

\section{Implications of volcaniclastic rocks in LIPs}

The types and volumes of volcaniclastic rocks present within LIPs are strongly related to: (1) LIP composition (i.e. mafic versus silicic); (2) primary volcanic fragmentation mechanisms; (3) environmental conditions of eruptions, particularly for mafic LIPs; and (4) environmental conditions of emplacement (e.g., continental flood basalt provinces versus oceanic plateaux).

\section{Primary Fragmentation Processes}

Mafic and silicic LIPs show a similar range of volcanic fragmentation and eruptive processes, but marked differences in the dominant eruptive styles (Table 2). In mafic LIPs, basaltic effusive eruptions dominate, whereas in silicic LIPs, silicic explosive eruptions dominate. Volcaniclastic deposits are more volumetrically significant for those mafic LIPs that contain: (1) substantial volumes $\left(10^{3}-10^{4} \mathrm{~km}^{3}\right)$ of silicic magma erupted as ignimbrite or other pyroclastic deposits (e.g., Paraná-Etendeka, Karoo, Afro-Arabia; Bryan et al., 2002), and/or where (2) external water sources were involved in mafic eruptions, leading to large-scale phreatomagmatic basaltic volcanism and resultant mafic volcaniclastic deposits with volumes of up to $10^{2}-10^{5} \mathrm{~km}^{3}$ (e.g., Siberian Traps, Ferrar, North Atlantic Igneous Province, Emeishan; Ross et al., 2005). These contrasting fragmentation mechanisms for the silicic and mafic magmas result in dramatically different eruption and emplacement processes. Knowing the relative contributions of effusive vs. pyroclatic deposit is critical for assessing the environmental impact of individual large-igneous provinces (Table 3 ).

The largest volumes $\left(10^{5}-10^{6} \mathrm{~km}^{3}\right)$ and proportions of volcaniclastic deposits are associated with silicic LIPs, for which volcaniclastic deposits alone can exceed the total eruptive volume and 
areal extent of some CFBPs (Bryan et al., 1997). Pyroclastic eruptions are critical in producing the large volumes of primary and reworked volcaniclastic rocks (Bryan et al., 1997, 2000). In contrast, in the CFBPs, the mafic effusive eruptions produce only minor volumes of coarse fragmental material (e.g., 'a 'a lava breccias, rubbly pahoehoe, scoria deposits). The common burial of fragmental deposits by the lava flows that formed them, combined with the limited fragmentation accompanying emplacement of pahoehoe to rubbly pahoehoe lavas that typify these provinces, are both important factors in limiting the amount of clastic material generated and available for reworking, and help explain why CFBPs produce only limited sedimentary signals in the geologic record.

\section{Vent Types}

The vent sites for some primary mafic volcaniclastic deposits in mafic LIPs have been identified (e.g. East and West Greenland: Pedersen et al., 1997, Ukstins Peate et al., 2003a, Larsen et al., 2003; Ferrar: Ross and White, 2006; Ross et al., 2008; Karoo: McClintock and White, 2008). In the Ferrar and Karoo provinces, exposed composite vent sites are called 'phreatocauldrons' (White and McClintock, 2001) because of the inferred phreatomagmatic fragmentation mechanism and the overall cauldron shape of the vent complexes, which can be described as 'nests of cross-cutting diatremes'. The mafic vent complexes described so far are apparently less than $10 \mathrm{~km}$ wide.

Known eruptive sources for silicic pyroclastic rocks in the CFBPs and along volcanic rifted margins are caldera-type complexes (e.g., Bell and Emeleus, 1988; Ewart et al., 2002, Bryan et al., 2002).. However, locations of silicic eruptive centres are poorly constrained in LIPs even for those provinces with well-mapped, abundant, extensive and voluminous silicic eruptive products (e.g., Paraná-Etendeka, Marsh et al., 2001; Afro-Arabian, Ukstins Peate et al., 2005). A key target for future work in LIPs is to locate and identify eruptive sites for silicic rocks, in order to constrain the volcanostratigraphy, eruption volumes and emplacement mechanisms.

Caldera complexes are typically parts of multiple-vent volcanic systems, which include numerous extracaldera (and intracaldera) monogenetic edifices. The mafic volcanic deposits consist of scoria/spatter cones and tuff rings/cones or maars, whereas silicic effusive eruptions 
generate lava domes or nested dome complexes (e.g., Bryan et al., 2000). Evidence for calderas as source vents for large-volume ignimbrites includes coarse lithic lag breccias and megabreccias within the ignimbrite eruptive units, and very thick, localised deposits inferred to be calderaponded (e.g., Ewart et al., 1992; Bryan et al., 2000; Swanson and McDowell, 1984; Swanson et al., 2006). Calderas in most silicic LIPs appear to range between 10 and $30 \mathrm{~km}$ in diameter, but larger calderas from $\sim 40 \mathrm{~km}$ up to $100 \mathrm{~km}$ in diameter have been inferred for the Chon Aike Province (Aragón et al., 1996; Riley et al., 2001). Remnants of many caldera complexes (cauldrons) are well-exposed in the deeply dissected Permo-Carboniferous Kennedy subprovince of northeastern Australia, where they exhibit a variety of geometries and composite arrangements, with individual calderas ranging from 10 to $40 \mathrm{~km}$ in diameter (Bain and Draper, 1997).

Locating calderas is also difficult in silicic LIPs because vent sites are often buried by caldera-fill deposits emplaced in the course of eruptions during caldera subsidence. Vent sites may also be buried by products, either primary or redeposited, of eruptions elsewhere in a province, given the volumes of volcanic material generated $\left(>10^{5} \mathrm{~km}^{3}\right)$ over relatively short periods of time. Later tectonism and erosion may also obscure vent sites (Bryan et al., 2002). Fewer than 15 calderas (Valles-type, Williams and McBirney, 1979) have, for example, been identified to date in the Sierra Madre Occidental (Aguirre-Díaz and Labarthe-Hernández, 2003), but given the preserved areal distribution of $393,000 \mathrm{~km}^{2}$, the existence of as many as 400 calderas has been postulated (McDowell and Clabaugh, 1979). New work in a small sector of the northern Sierra Madre Occidental indicates a relatively high density of locally overlapping calderas similar to those in the coeval San Juan volcanic field in Colorado (Swanson et al., 2006). The problem of caldera recognition is even more extreme for the Whitsunday silicic LIP, where only five eruptive centres have been identified in a province with an extrusive output of $>2.2 \times 10^{6} \mathrm{~km}^{3}$ (Ewart et al., 1992; Bryan et al., 2000; Bryan, 2007).

Recent work also suggests that some rhyolitic ignimbrites were emplaced from extensive volcano-tectonic fissures linked to regional extension. Welded pyroclastic dykes have been reported from the Whitsunday (Bryan et al., 2000), Sierra Madre Occidental (Aguirre-Díaz and Labarthe-Hernández, 2003) and Chon Aike (Pankhurst et al., 1998) silicic LIPs. In the Sierra 
Madre Occidental, welded pyroclastic dykes or fissures are up to several kilometres in length and associated with regional Basin and Range extensional graben-bounding faults (Aguirre-Díaz and Labarthe-Hernández, 2003). Although a general spatial overlap between silicic volcanism and extensional faulting is known, the timing of volcanic pulses and major tectonic episodes is not well-constrained for these provinces.

\section{Volcanic Environments}

Eruptive and depositional environments for many of the better-studied LIPs, both mafic and silicic, were primarily subaerial. On continents, wet environments fostering phreatomagmatic fragmentation and hyaloclastite formation are dominated by intra-caldera lakes or volcanotectonic rift basins developed before or during LIP magmatism. In contrast, the Late Permian Emeishan flood basalt province appears to have been emplaced onto a shallow marine carbonate platform developed across the Yangtze Craton in southwest China. Phreatomagmatic activity produced limestone-bearing mafic volcaniclastic rocks and accretionary lapilli tuffs, and submarine emplacement of basaltic pillow lava occurred during the early eruptive stages and in the core of the Emeishan flood basalt province. The lateral and temporal distributions of these rocks within the volcanic pile ('inner zone' of He et al., 2003) suggest that the upper limits of the accommodation space remained close to, or below, sea level during the early stages of volcanism, indicating that no kilometre-scale prevolcanic lithospheric doming, such as predicted by the mantle plume hypothesis, took place (cf. He et al., 2003; Xu et al., 2004; Campbell, 2005).

Emplacement during continental LIP volcanism of kilometres-thick pyroclastic piles over short time spans may inhibit formation of sizeable bodies of surface water if the deposits are highly permeable or if the climate is arid. Ignimbrite surfaces commonly have relatively modest permeabilities, however, as illustrated by the formation of a large temporary lake atop the Taupo ignimbrite (Manville, 2001), and blocking of streams by ignimbrites commonly leads to drainage disruption, development of new lakes, and deepening of existing ones (Manville et al., 1999; Manville, 2002). Flood basalt lava flows may develop significant topography by differential inflation across a lava flow field (e.g. Larsen et al., 2006), but the extremely high permeability of young lava fields makes surface ponding of water unlikely unless the groundwater table rises above the flows. An example of this extreme permeability is provided by the Snake River Plain 
aquifer, which occupies a Cenozoic stack of basaltic lavas up to $3 \mathrm{~km}$ thick (Greeley, 1982). It is "one of the most permeable large aquifer systems in the world" (p. 7, Hackett et al., 1986). Some wells demonstrate transmissivities in excess of 50,000 $\mathrm{m}^{2} /$ day (Welhan and Reed, 1997), with the bulk of water moving along tops and bases of pahoehoe flow units, although jointing gives even massive flow interiors moderate lateral permeability (Welhan and Reed, 1997). The "Big Lost River", discharging about $\sim 70 \mathrm{~m}^{3} / \mathrm{s}$ before flowing onto the lavas (Ostenaa et al., 2002), simply disappears into the surface of the aquifer, with discharge elsewhere feeding springs in excess of 7000 cfs ( Hackett et al., 1986; $200 \mathrm{~m}^{3} /$ second). Despite the high permeability of young lava fields, however, emplacement of lavas may partially impound streams with sufficient discharge, and this may explain the abundance of small pillow-lava complexes interspersed within the sequences across the Columbia River Basalt Province (see Hooper, 1997 and references therein). Where later eruptions encounter ground or surface water, explosive or passive magma-water interactions may take place, as in West Greenland, where lavas of the Maligat Formation erupted from subaerial vents and flowed into a deep and extensive paleolake, generating a complex of hyaloclastites and rootless cones up to $200 \mathrm{~m}$ wide and $25 \mathrm{~m}$ high (Larsen et al., 2006). Interaction of mafic magmas with water also appears to be more prevalent when volcanism is associated with active lithospheric extension and subsidence. An example of this is the change from non explosive, terrestrial flood basalt eruptions to highly explosive basaltic phreatomagmatic/phreatoplinian eruptions towards the close of volcanic activity in the North Atlantic Igneous Province, related to flooding of the nascent North Atlantic Rift (Larsen et al., 2003, Jolley and Widdowson, 2005).

Phreatomagmatic activity has also been common during opening stages of flood volcanism in sedimentary basins, which have a variety of water reservoirs (aquifers, lakes, rivers, shallow seas) that can supply the water for explosive eruptions (Ross et al., 2005). Non-explosive hyaloclastic fragmentation processes generating volcaniclastic deposits in association with seafloor lavas are presumably prevalent in initial deep-water eruptions of oceanic plateaux. Recent results from the Ocean Drilling Program (ODP) on the Ontong-Java Plateau (Leg 192, Site 1184; Shipboard Scientific Party, 2001) show, however, that mafic volcaniclastic deposits of phreatomagmatic origin can form deposits of significant thickness in such plateaux, particularly where basaltic volcanism occurred at shallow water depths and/or was emergent (Thordarson, 
2004). Evidence from ODP Legs 119, 120, and 183 also clearly demonstrates that large parts of the Kerguelen oceanic plateau were originally subaerial during plateau construction (Frey et al., 2000).

In summary, the diversity of volcaniclastic material generated during LIP formation reflects the diversity of magma composition, eruption mechanisms and environmental conditions during eruptions, and in primary volcaniclastic emplacement processes as well as those effecting subsequent remobilisation. The volcaniclastic deposits are unique in the richness of information they offer regarding environmental conditions during volcanic activity, and represent the most explosive of large igneous events. By better understanding emplacement of the sometimes undervalued volcaniclastic component of LIPs, we can address and constrain key issues of LIP petrogenesis and global impact.

\section{Discussion and conclusions}

With the accumulation of studies addressing the physical processes of eruptions in LIPs, it becomes ever more apparent that all the complexity observed in historical eruptions is present, but at a range of scales, and to a far lesser extent, rates, extending from the normal to the extraordinary. In a sense, this is unsurprising - LIPs are, after all, large, and the product of many large magnitude eruptions.

In other ways, however, the similarities with small-volume, modern eruptions may allow us to use LIPs to diagnose behavioural aspects of smaller eruptions. In particular, some provinces expose large tracts of shallow subvolcanic intrusions, which are presumed to represent the magma-feeding systems for numerous effusive eruptions over large areas. Although magma delivery processes may be significantly different for provinces that provide millions of $\mathrm{km}^{3}$ of magma for eruptions, these tracts can nevertheless offer important insights into the physical operation of other magmatic plumbing systems. With so much magma pumped into the crust, there are mappable geological effects that in smaller systems might require high-resolution mapping or geophysical studies to identify. In provinces such as the Ferrar, the results of this high magma throughput are well-exposed at a level of detail that cannot be matched by subsurface geophysical investigations, and in a variety unmatched in any single smaller eroded 
volcanic system.

In conclusion, here is a listing of major findings from studies on LIPs, with an admitted emphasis on continental examples.

- LIPs must have large plumbing systems that, at least for CFBPs, include an extensive network of crustal sills and dikes, the emplacement of which subdivides intervening country rock into differentially uplifted and tilted blocks;

- Shallowing sills locally break through to the surface, disrupting and enveloping blocks of country rock;

- Flood basaltic lava flows are emplaced as flow fields that advance and thicken by inflation for years or decades during sustained eruptions with fluxes in the range known from other more recent basaltic eruptions;

- Fragmental deposits proximal to flood basalt vents provide evidence for periods of high fountaining and sub-plinian plume dispersal, and based on smaller-scale modern analogs, have been associated with regional climate modification;

- Many CFBPs and volcanic passive margins contain significant volumes of mafic volcaniclastic deposits, and where well-studied, these revealed evidence for extensive phreatomagmatic eruptions that preceded flood-basalt emplacement;

- Eruptions producing mafic volcaniclastic deposits have produced caldera-scale vent complexes and substantial mafic pyroclastic-flow deposits, the former in some cases subsequently occupied by lakes;

- Silicic pyroclastic eruptions, both in largely basaltic continental fields and in silicic LIPs, have emplaced deposits as or more voluminous than individual flood-basalt units, and with much greater dispersal;

- Like flood basalt lava eruptions, ignimbrite-forming eruptions, as evident from the silicic LIPs, can also occur from fissures that tap stored magma through regional faults.

- Many LIPs have been constructed by multiple long-lived effusive eruptions producing the typical flood basalt plateaus of CFBPs, volcanic passive margins and oceanic plateaus, but in other cases explosive volcanism has been the dominant eruptive style (e.g., Siberian, silicic LIPs). Dominance of explosive volcanism in LIPs is a result of either 
magma composition, where erupted compositions are dominantly silicic, and/or of environmental conditions at eruptive sites conducive for large-scale phreatomagmatism.

- The spatial-temporal relationships between flood basalt lavas and volcaniclastic deposits during LIP formation can provide important constraints on the relative timing of LIP magmatism, extension, kilometre-scale uplift, and palaeoenvironmental changes. These constraints can significantly advance our aim of understanding the earth-scale causative processes of LIP events.

\section{Acknowledgements}

This paper evolved from one developed for a special issue of Journal of Volcanology and Geothermal Research initiated and lead-edited by Ian Skilling. Antarctica New Zealand provided support for the work of P.-S. Ross, J. White and Th. Thordarson in Antarctica, and J.White acknowledges support from GNS Science (NZ; PGSF contract CO5X0402) for research on phreatomagmatic processes. S. Bryan thanks Tony Ewart, Goonie Marsh, David Peate and Mike Mawby for discussions on aspects of this manuscript; field work collaborations with Luca Ferrari in the Sierra Madre Occidental; and Yigang Xu, Bin He, Hong Zhong, and Zhaocong Zhang, leaders of the May 19-27, 2006 post-IAVCEI conference field trip to Emeishan, for providing the opportunity to make new observations on the mafic volcaniclastic rocks in the Emeishan flood basalt province. P.-S. Ross thanks M. Jébrak for hosting him at Université du Québec à Montréal (Canada) during the preparation of the manuscript, and G. Ernst for encouragement. Ingrid Ukstins Peate is thanked for reviewing an early version of the manuscript. 


\section{References}

Aguirre-Díaz, G.J., Labarthe-Hernández, G., 2003. Fissure ignimbrites; fissure-source origin for voluminous ignimbrites of the Sierra Madre Occidental and its relationship with basin and range faulting. Geology 31, 773-776. (doi: 10.1130/G19665.1)

Allen, S.R., McPhie, J., 2002. The Eucarro Rhyolite, Gawler Range Volcanics, South Australia; a $>675 \mathrm{~km}^{3}$, compositionally zoned lava of Mesoproterozoic age. Geol. Soc. Am. Bull. 114,1592-1609.

Allen, S.R., Simpson, C.J., McPhie, J., Daly, S.J., 2003. Stratigraphy, distribution and geochemistry of widespread felsic volcanic units in the Mesoproterozoic Gawler Range Volcanics, South Australia. Aust. J. Earth Sci. 50, 97-112.

Anderson, E.M., 1951 The dynamics of faulting and dyke formation with application to Britain, 2nd Edition, Oliver \& Boyd, Edinburgh.

Aragón, E, Rodriguez, A.M.I., Benialgo, A.1996. A calderas field at the Marifil Formation, new volcanogenic interpretation, Norpatagonian Massif, Argentina. J. S. Amer. Earth Sci. 9, 321-328. (doi:10.1016/S0895-9811(96)00017-X).

Axen, G.J., Taylor, W.J., Bartley, J.M., 1993. Space time patterns and tectonic controls of Tertiary extension and magmatism in the Great Basin of the Western United States. Geol. Soc. Am. Bull. 105, 56-76.

Bain J.H.C., Draper J.J. (eds), 1997. North Queensland Geology. Australian Geological Survey Organisation, Canberra, $600 \mathrm{p}$.

Baker, J., Snee, L., Menzies, M., 1996. A brief Oligocene period of flood volcanism in Yemen: implications for the duration and rate of continental flood volcanism at the Afro-Arabian triple junction. Earth Planet. Sci. Lett. 138, 39-55.

Baragar, W.R.A., Ernst, R.E., Hulbert, L., Peterson, T. 1996. Longitudinal petrochemical variation in the Mackenzie dyke swarm, northwestern Canadian Shield. J. Petrol. 37. 317359.

Bell, B.R., Emeleus, C.H., 1988. A review of silicic pyroclastic rocks of the British Tertiary Volcanic Province. In Morton, A.C., and Parson, L.M., eds., Early Tertiary volcanism and the opening of the NE Atlantic: Geol. Soc. London Spec. Publ. 39, 365-379.

Bellieni G, Cominchiaramonti P, Marques LS, Melfi AJ, Nardy AJR, Papatrechas C, Piccirillo EM, Roisenberg A, Stolfa D (1986) Petrogenetic Aspects of Acid and Basaltic Lavas from 
the Parana Plateau (Brazil) - Geological, Mineralogical and Petrochemical Relationships. Journal of Petrology 27(4):915-944

Best, M.G., Christiansen, E.H., 1991. Limited extension during peak Tertiary volcanism, Great Basin of Nevada and Utah. J. Geophys. Res. 96, 13,509-13,528.

Blake, T.S., 2001. Cyclic continental mafic tuff and flood basalt volcanism in the Late Archaean Nullagine and Mount Jope supersequences in the Eastern Pilbara, Western Australia. Precambrian Res. 107, 139- 177.

Blake, T.S., Buick, R., Brown, S.J.A., Barley, M.E., 2004. Geochronology of a Late Archaean flood basalt province in the Pilbara Craton, Australia: constraints on basin evolution, volcanic and sedimentary accumulation, and continental drift rates. Precambrian Res. 133, 143-173.

Bondre NR, Dole G, Phadnis VM, Duraiswami R, Kale VS (2000) Inflated pahoehoe lavas from the Sangamner area of the western Deccan Volcanic Province. Current Science 78:10041007

Bondre, N. R., R. A. Duraiswami, G. Dole, 2004. Morphology and emplacement of flows from the Deccan Volcanic Province and the Columbia-Oregon Plateau flood basalts: Implications for flood basalt emplacement. Bulletin of Volcanology 66: 29-45.

Bondre, N. R., R. A. Duraiswami, G. Dole (2004). A brief comparison of lava flows from the Deccan Volcanic Province, India. Proc: Indian Acad. Sci (Earth Planet Sci.) 113, 809-817.

Branney, M.J., Kokelaar, P., 1992. A reappraisal of ignimbrite emplacement: progressive aggradation and changes from particulate to non-particulate flow during emplacement of high-grade ignimbrite. Bull. Volcanol. 54, 504-520.

Bryan, S.E. 2007. Silicic Large Igneous Provinces. Episodes, 30, 20-31.

Bryan S.E., Ernst, R.E. 2008. Revised definition of Large Igneous Provinces (LIPs). Earth Science Reviews 86, 175-202.

Bryan, S.E., Constantine, A.E., Stephens, C.J., Ewart, A, Schön, R.W., Parianos, J., 1997. Early Cretaceous volcano-sedimentary successions along the eastern Australian continental margin: Implications for the break-up of eastern Gondwana. Earth Planet. Sci. Lett. 153, 85-102. (doi:10.1016/S0012-821X(97)00124-6)

Bryan, S.E., Ewart, A., Stephens, C.J., Parianos J., Downes, P.J., 2000. The Whitsunday Volcanic Province, Central Queensland, Australia: lithological and stratigraphic 
investigations of a silicic-dominated large igneous province. J. Volcanol. Geotherm. Res. 99, 55-78. (doi:10.1016/S0377-0273(00)00157-8).

Bryan, S.E., Holcombe, R.J., Fielding, C.R., 2003. Reply to: "The Yarrol terrane of the northern New England Fold Belt: Forearc or backarc?" Discussion by Murray, C.G., Blake, P.R., Hutton, L.J., Withnall, I.W., Hayward, M.A., Simpson, G.A., Fordham, B.G. Aust. J. Earth Sci. 50, 271-293.

Bryan, S.E., Riley, T.R., Jerram, D.A., Stephens, C.J., Leat, P.L., 2002. Silicic volcanism: An undervalued component of large igneous provinces and volcanic rifted margins. In: Menzies, M.A., Klemperer, S.L., Ebinger, C.J., Baker, J. (Eds.), Volcanic Rifted Margins. Geol. Soi. Am. Special Paper 362, pp. 97-118.

Cameron, M., Bagby, W.C., Cameron, K.L., 1980. Petrogenesis of voluminous mid-Tertiary ignimbrites of the Sierra Madre Occidental. Contrib. Mineral. Petrol. 74, 271-284.

Campbell, I.H., 2005. Large Igneous Provinces and the mantle plume hypothesis. Elements, 1, 265-269.

Chevallier, L., and Woodward A., 1999, Morpho-tectonics and mechanism of emplacement of the dolerite sills of the western Karoo, South Africa: South African Journal of Geology 102 (1), p. 43-54.

Cleverly, R.W., 1979. The volcanic geology of the Lebombo monocline in Swaziland. Trans. Geol. Soc. South Africa 82, 227-230.

Coffin, M.F., Eldholm, O., 1994. Large igneous provinces: crustal structure, dimensions, and external consequences. Rev. Geophys. 32, 1-36.

Cole, J.W., Milner, D.M., Spinks, K.D., 2005. Calderas and caldera structures: a review. EarthSci. Rev., 69, 1-26. (doi:10.1016/j.earscirev.2004.06.004)

Crisp, J.A., 1984. Rates of magma emplacement and volcanic output. Journal of Volcanology and Geothermal Research, 20: 177-211.

Czamanske, G.K., Gurevitch, A.B., Fedorenko, V., Simonov, O., 1998. Demise of the Siberian plume: paleogeographic and paleotectonic reconstruction from the prevolcanic and volcanic record, north-central Siberia. Int. Geol. Rev. 40, 95-115.

Daly, S.J., Fanning, C.M., Fairclough, M.C., 1998. Tectonic evolution and exploration potential of the Gawler Craton, South Australia. AGSO J. Aust. Geol. Geophys. 17, 145-168.

Duraiswami, R. A., N. R. Bondre, et al. (2001). Tumuli and associated features from the western 
Deccan Volcanic Province, India. Bulletin of Volcanology 63: 435-442.

Duraiswami, R. A., G. Dole, Bondre N.R. 2002. Morphology and structure of flow-lobe tumuli from Pune and Dhule areas, western Deccan Volcanic Province. Journal of Volcanology and Geothermal Research 121: 195-217.

Duraiswami, R. A., G. Dole, Bondre N.R. 2003. Slabby pahoehoe from the western Deccan Volcanic Province: evidence for incipient pahoehoe-aa transitions. Journal of Geological Society of India 60, 57-65.

Du Toit, A.L., 1954. The Geology of South Africa. Oliver and Boyd, Edinburgh, 611 pp.

Elliot, D.H., Hanson, R.E., 2001. Origin of widespread, exceptionally thick basaltic phreatomagmatic tuff breccia in the Middle Jurassic Prebble and Mawson formations, Antarctica. J. Volcanol. Geotherm. Res. 111, 183-201.

Elliot, D.H. and Fleming, T.H., 2004. Occurrence and dispersal of magmas in the Jurassic Ferrar Large Igneous Province, Antarctica. Gondwana Research, 7(1): 223-237.

Elliot, D.H., Fleming, T.H., 2008. Physical Volcanology of the Ferrar Large Igneous Province, Antarctica. J. Volcanol. Geotherm. Res.in press, doi 10.1016/j.jvolgeores.2006.02.0016

Ellis, D., Bell, B.R., Jolley, D.W., O'Callaghan, M., 2002. The stratigraphy, environment of eruption and age of the Faroes Lava Group, NE Atlantic Ocean. In: D.W. Jolley and B.R. Bell (Eds.), The North Atlantic Igneous Province: Stratigraphy, Tectonic, Volcanic and Magmatic Processes. Geol. Soc. Special Pub. 197, pp. 253-269.

Ernst, R.E. and Baragar, W.R.A., 1992. Evidence from Magnetic Fabric for the Flow Pattern of Magma in the Mackenzie Giant Radiating Dyke Swarm. Nature, 356(6369): 511-513.

Ernst, R.E., Buchan, K.L., 1997. Giant radiating dyke swarms: their use in identifying pre-Mesozoic large igneous provinces and mantle plumes. In: Mahoney, J., Coffin, M. (Eds.), Large Igneous Provinces: Continental, Oceanic, and Planetary Volcanism. Geophysical Monograph Series, vol. 100. American Geophysical Union, pp. 297- 333.

Ernst, R.E., Buchan, K.L., 2001. Large mafic magmatic events through time and links to mantle-plume heads. In: Ernst, R.E., Buchan, K.L. (Eds.), Mantle Plumes: Their Identification Through Time. Geol. Soc. Am. Spec. Pap. 352, 483- 575.

Ernst, R.E. and Desnoyers, D.W., 2004. Lessons from Venus for understanding mantle plumes on Earth. Physics of the Earth and Planetary Interiors, 146(1-2): 195-229.

Ernst, R.E., Buchan, K.L., Campbell, I.H., 2005. Frontiers in Large Igneous Province research. 
Lithos 79, 271-297.

Ewart, A., Marsh, J.S., Milner, S.C., Duncan, A.R., Kamber, B.S., Armstrong, R.A., $2004 a$. Petrology and geochemistry of Early Cretaceous bimodal continental flood volcanism of the NW Etendeka, Namibia; Part 2, Characteristics and petrogenesis of the high- Ti latite and high-Ti and low-Ti voluminous quartz latite eruptives. J. Petrol. 45, 107-138.

Ewart, A., Milner, S.C., Armstrong, R.A., Duncan, A.R., 1998a. Etendeka Volcanism of the Goboboseb Mountains and Messum Igneous Complex, Namibia. Part II: Voluminous quartz latite volcanism of the Awahab magma system. J. Petrol. 39 (2), 227-253.

Ewart, A., Milner, S.C., Duncan A.R., Bailey, M. 2002. The Cretaceous Messum igneous complex, S.W. Etendeka, Namibia: reinterpretation in terms of a downsag-cauldron subsidence model. J. Volcanol. Geotherm. Res. 114, 251-273.

Ewart, A., Schön, R.W., Chappell, B.W., 1992. The Cretaceous volcanic-plutonic province of the central Queensland (Australia) coast - a rift related "calc-alkaline" province. Trans. R. Soc. Edinburgh, Earth Sci. 83, 327-345.

Ferrari L., Lopez M.M., Rosas E.J., 2002. Ignimbrite flare-up and deformation in the southern Sierra Madre Occidental, western Mexico; implications for the late subduction history of the Farallon Plate. Tectonics, 21,17, 1-23.

Ferrari, L., Valencia-Moreno, M., and Bryan S.E., 2007. Magmatism and Tectonics of the Sierra Madre Occidental and their relation to the evolution of the western margin of North America. Geol. Soc.Am. Spec. Pap. 442, in press.

Fisher, R.V., Schmincke, H.-U., 1984. Pyroclastic Rocks. Springer-Verlag, Berlin, 472p.

Frey, F.A., Coffin, M.F., Wallace, P.J., Weis, D., Zhao, X., et al., 2000. Origin and evolution of a submarine large igneous province: the Kerguelen Plateau and Broken Ridge, southern Indian Ocean. Earth Planet. Sci. Lett., 176, 73-89.

Fuller, R.E., 1928. The Asotin Craters of the Columbia River Basalt. J. Geol. 36, 56-74.

Gans, P.B., Mahood, G.A., Schermer, E.R., 1989. Synextensional magmatism in the Basin and Range Province; a case study from the eastern Great Basin. Geol. Soc. Am. Spec. Pap. 233, 1-53.

Garland, F.E.,1994, The Parana rhyolites, southern Brazil: their petrogenetic relationship to the associated flood basalts. Unpublished PhD thesis, The Open University, $354 \mathrm{pp}$.

Garland, F., Hawkesworth, C. J., Mantovani, S. M., 1995. Description and petrogenesis of the 
Paraná rhyolites, southern Brazil. J. Petrol. 36, 1193-1227.

Guilbaud M-N, Self S, Thordarson Th, Blake S, 2005, Flow formation, surface morphology, and emplacement mechanism of the AD 1783-4 Laki lava. Special Paper of Geological Society of America on Kinematics and Dynamics of Lava Flows (eds. M. Manga and G. Ventura), pg.

Gunn, B.M. and Warren, G., 1962. Geology of Victoria Land between the Mawson and Mulock Glaciers, Antarctica. New Zealand Geological Survey Bulletin, 71: 1-157.

Grattan J., 2005. Pollution and paradigms: lessons from Icelandic volcanism for continental flood basalt studies. Lithos, 79, 343-353.

Greeley, R., 1982. The Snake River Plain, Idaho - Representative of a New Category of Volcanism. J. Geophys. Res. 87, 2705-2712

Hackett, W., Pelton, J. and Brockway, C., 1986. Geohydrologic story of the eastern Snake River Plain and the Idaho National Engineering Laboratory. U.S. Dept. Energy, Idaho National Engineering Laboratory, $32 \mathrm{pp}$.

Hanson, R.E., Elliot, D.H., 1996. Rift-related Jurassic phreatomagmatism in the central Transantarctic Mountains: precursory stage to flood-basalt effusion. Bull. Volcanol. 58, 327-347.

Hatton, C.J., Schweitzer, J.K., 1995. Evidence for synchronous extrusive and intrusive Bushveld magmatism. J African Earth Sci. 21, 579-594.

Hawkesworth, C.J. et al., 2000. Time scales of crystal fractionation in magma chambers Integrating physical, isotopic and geochemical perspectives. Journal of Petrology, 41: 9911006.

He, B. Xu, Y-G., Chung, S-L., Xiao, L., Wang Y., 2003. Sedimentary evidence for a rapid, kilometre-scale crustal doming prior to the eruption of the Emeishan flood basalts. Earth and Planetary Science Letters 213, 391-405.

Head, J.W. and Kreslavsky, M.A., 2002. Northern lowlands of Mars: Evidence for widespread volcanic flooding and tectonic deformation in the Hesperian Period. Journal of Geophysical Research-Planets, 107(E1): http://dx.doi.org/10.1029/2000JE001445

Heister, L.E., O'Day, P.A., Brooks, C.K., Neuhoff, P.S., Bird, D.K., 2001. Pyroclastic deposits within the East Greenland Tertiary flood basalts. J. Geol. Soc. (Lond.) 158, 269-284.

Ho, A.M., Cashman, K.V., 1997. Temperature constraints on the Ginkgo Flow of the Columbia 
River Basalt Group. Geology 25, 403-406.

Hon, K., Kauahikaua, J., Denlinger, R., Mackay, K., 1994. Emplacement and inflation of pahoehoe sheet flows; observations and measurements of active lava flows on Kilauea Volcano, Hawaii. Geological Society of America Bulletin 106 (3), 351-370.

Hooper, P.R. 1990. The timing of crustal extension and the eruption of continental flood basalts. Nature 345, 246-249.

Hooper, P.R., 1996, The Pomona Flow, Columbia River Basalts. In Abstracts of Chapman Conference on Long Lava Flows, Townsville, Australia, 1996.

Hooper, P.R., 1997. The Columbia River flood basalt province: current status. In: J.J. Mahoney and M.F. Coffin (Eds.), Large Igneous Provinces: Continental, Oceanic, and Planetary Flood Volcanism. Am. Geophys. Union, Geophysical Monograph 100, pp. 1-27.

Houghton, B.F., Wilson, C.J.N., Smith I.E.M., 1999. Shallow-seated controls on styles of explosive basaltic volcanism; a case study from New Zealand. Journal of Volcanology and Geothermal Research, 91, 97-120.

Jay, A.E., 2005. Volcanic architecture of the Deccan Traps, Western Maharashtra, India: an integrated chemostratigraphic and palaeomagnetic study. Ph.D. Thesis, The Open University, Milton Keynes, 360 p.

Jerram D.A. 2002, Volcanology and facies architecture of flood basalts. Geological Society of American Special Paper 362, 121-135

Jerram, D.A., Stollhofen, H., 2002. Lava-sediment interaction in desert settings; are all peperitelike textures the result of magma-water interaction? J. Volcanol. Geotherm. Res. 114, 231249.

Jerram, D.A., Widdowson, M., 2005. The anatomy of Continental Flood Basalt Provinces: geological constraints on the processes and products of flood basalt volcanism. Lithos 79 (3-4), 385-405.

Johnson, C.M., 1991. Large scale crust formation and lithosphere modification beneath Middle to Late Cenozoic calderas and volcanic fields, western North America. J. Geophys. Res. 96, $13,845-13,507$.

Johnson, R.W. (ed.), 1989. Intraplate Volcanism in Eastern Australia and New Zealand. Cambridge University Press, Sydney, pp. 1-408.

Johnson, M.R., Van Vuuren, C.J., Hegenberger, W.F., Key, R. and Show, U., 1996. Stratigraphy 
of the Karoo Supergroup in southern Africa: an overview. Journal of African Earth Sciences, 23(1): 3-15.

Jolley, D.W., Widdowson, M., 2005. Did Paleogene North Atlantic rift-related eruptions drive early Eocene climate cooling? Lithos 79, 355-366. (doi:10.1016/j.lithos.2004.09.007)

Kerr, A.C., 1995. The geochemical stratigraphy, field relations and temporal variation of the Mull-Morvern Tertiary lava succession, NW Scotland. Trans. R. Soc. Edinburgh Earth Sci., 86, 35-47.

Kerr, A.C., 2003. Oceanic Plateaus. In: Rudnick, R., (Ed.) The Crust. Treatise on Geochemistry, volume 3, 537-565.

Kerr, A.C., Mahoney, J.J., 2007. Oceanic plateaus: Problematic plumes, potential paradigms. Chemical Geology 241, 332-353.

Kerr, A.C., Tarney, J., Kempton, P.D., Pringle, M., Nivia, A., 2004. Mafic pegmatites intruding oceanic plateau gabbros and ultramafic cumulates from Bolivar, Colombia: evidence for a 'wet' mantle plume? J. Petrol., 45, 1877-1906.

Keszthelyi, L., 2002. Classification of mafic lava flows from ODP leg 183 [on line]. Proc. Ocean Drill. Program, Sci. Res 183 [http//www.odp.tamu.edu/publications/183$\mathrm{SR} / 012 / 012 . \mathrm{htm}]$.

Keszthelyi, L., A. S. McEwen, T. Thordarson (2000). Terrestrial analogs and thermal models for Martian flood lavas. Journal of Geophysical Research-Planets 105: 15027- 15049.

Keszthelyi L, S Self, Th Thordarson, 1999, Application of recent studies on the emplacement of basaltic lava flows to the Deccan Traps, in K V Subbarao (ed.), Deccan Volcanic Province, Geological Society of India Memoir, 43(1), Geological Society of India, Bangalore, p. 485-520.

Keszthelyi L., T. Thordarson, A. McEwen, H. Haack, M.-N. Guilbaud, S. Self, M. J. Rossi, 2004, Icelandic analogs to Martian flood lavas. Geochem. Geophys. Geosyst. $\left(G^{3}\right), 5$, Q11014, doi:10.1029/2004GC000758.

Keszthelyi, L. and Self, S., 1998. Some physical requirements for the emplacement of long basaltic lava flows. Journal of Geophysical Research 103 (b11), 27447-27464.

Khan, W., McCormick, G.R., Reagan, M.K., 1999. Parh Group basalts of the northeastern Balachistan, Pakistan: Precursors to the Deccan Traps. In: A. Macfarlane, R.B. Sorkhabi and J. Quade (Eds.), Himalaya and Tibet: Mountain Roots to Mountain Tops. Geol. Soc. 
Am. Special Paper 328, pp. 59-74.

Kirstein, L.A., Peate, D.W., Hawkesworth, C.J., Turner, S.P., Harris, C., Mantovani, M., 2000. Early Cretaceous basaltic and rhyolitic magmatism in southern Uruguay associated with the opening of the South Atlantic. J. Petrol. 41, 1413-1438.

Knox, R.W.O., Morton, A.C., 1988. The record of early Tertiary N Atlantic volcanism in sediments of the North Sea Basin. In: A.C. Morton and L.M. Parson (Eds.), Early Tertiary Volcanism and the Opening of the NE Atlantic. Geol. Soc. Special Pub. 39, pp. 407-419.

Larsen, L.M., Fitton, J.G., Pedersen, A.K., 2003. Paleogene volcanic ash layers in the Danish Basin: compositions and source areas in the North Atlantic Igneous Province. Lithos 71, 47-80. (doi:10.1016/j.lithos.2003.07.001)

Lightfoot, P.C., Hawkesworth, C.J., Sethna, S. F., 1987. Petrogenesis of rhyolites and trachytes from the Deccan Trap: $\mathrm{Sr}, \mathrm{Nd}$ and $\mathrm{Pb}$ isotope and trace element evidence. Contrib. Mineral. Petrol. 95, 44-54.

Lipman, P.W., Prostka, H.J., Christiansen, R.L., 1972. Cenozoic volcanism and plate tectonic evolution of the western United States, Part 1: Early and Middle Cenozoic. Phil. Trans. R. Soc. London, Series A 271, 217248.

Major, J.J., Pierson, T.C., Dinehart R.L., Costa, J.E. 2000. Sediment yield following severe volcanic disturbance - a two decade perspective from Mount St. Helens, Geology 28, 819822.

Malthe-Sørenssen, A., Planke, S., Svensen, H. and Jamtveit, B., 2004. Formation of saucershaped sills. In: Breitkreuz C, Petford N (eds.) Geological Society of London Special Publication 234, 215-227.

Marsh, B.D., 1996. Solidification fronts and magmatic evolution. Mineralogical Magazine, 60: 540.

Marsh, B.D., 2004. A magmatic mush column Rosetta Stone: the McMurdo Dry Valleys of Antarctica. EOS, 85(47): 497,592.

Manville, V. (2001) Sedimentology and history of Lake Reporoa: an ephemeral supra-ignimbrite lake, Taupo Volcanic Zone, New Zealand. In: Volcaniclastic Sedimentation in Lacustrine Settings (Eds J.D.L. White and N.R. Riggs), Int. Assoc. Sedimentol. Spec. Pub. 30, 109140.

Manville, V., 2002. Sedimentary and geomorphic responses to ignimbrite emplacement: 
Readjustment of the Waikato River after the AD 181 Taupo Eruption, New Zealand. J. Geol. 110, 519-541.

Manville, V., Wilson, C.J.N., 2004. The 26.5 ka Oruanui eruption, New Zealand: a review of the roles of volcanism and climate in the post-eruptive sedimentary response. N.Z. J. Geol. Geophys. 47, 422-442.

Manville, V., White, J.D.L., Houghton, B.F. and Wilson, C.J.N., 1999. Paleohydrology and sedimentology of a post-1.8 ka breakout flood from intracaldera Lake Taupo, North Island, New Zealand. Geol. Soc. Am. Bull. 111, 1435-1447

Manville V., Newton E.H., White J.D.L., 2005. Fluvial responses to volcanism: resedimentation of the 1800a Taupo ignimbrite eruption in the Rangitaiki River catchment, North Island, New Zealand. Geomorphology 65, 49-70.

Marsh, J.S., Ewart, A., Milner, S.C., Duncan, A.R., Miller, R.McG., 2001. The Etendeka igneous province; magma types and their stratigraphic distribution with implications for the evolution of the Parana-Etendeka flood basalt province. Bull. Volcanol. 62, 464-486.

Mason, B.G., Pyle, D.M., Oppenheimer, C., 2004. The size and frequency of the largest explosive eruptions on Earth. Bull. Volcanol. 66, 735-748. (doi:10.1007/s00445-004-03559)

Mawby, M.R., Bryan, S.E., Jerram, D.A., Davidson, J.P. 2006. How are 'Super' eruptions preserved in the past? Volcanological features of large volume silicic eruptions of the Paraná-Etendeka. Eos Trans. Am. Geophys. Union 87(52), Fall Meeting Supplement, Abstract V33-0683.

McClintock, M.K., 2001. Phreatomagmatism at Coombs Hills, Antarctica: Magma-water supervolcanism in a wet, failed rift. unpublished MSc Thesis, University of Otago, Dunedin, New Zealand, $191 \mathrm{pp}$.

McClintock, M.K., White, J.D.L, 2002. Granulation of weak rock as a precursor to peperite formation: coal peperite, Coombs Hills, Antarctica . J. Volcanol. Geotherm. Res 114, 205217.

McClintock, M.K., White, J.D.L., 2006. Large-volume phreatomagmatic vent complex at Coombs Hills, Antarctica records wet, explosive initiation of flood basalt volcanism in the Ferrar LIP. Bull. Volcanol. 68, 215-219. 
McClintock, M., White, J.D.L., Houghton, B.F., Skilling, I.P., 2008. Physical volcanology of a large crater-complex within the Karoo flood basalt, Sterkspruit, South Africa. J. Volcanol. Geotherm. Res. in press, doi 10.1016/j.jvolgeores.2005.11.012

McDowell, F.W., Clabaugh, S.E., 1979. Ignimbrites of the Sierra Madre Occidental and their relation to the tectonic history of western Mexico. Geol. Soc. Am. Spec. Pap. 180, 113-124.

McPhie, J., Doyle, M., and Allen, R., 1993. Volcanic Textures: A guide to the interpretation of textures in volcanic rocks: Centre for Ore Deposit and Exploration Studies, University of Tasmania, Hobart, 196 p.

Menzies, M.A., Klemperer, S.L., Ebinger, C.J., Baker, J., 2002. Characteristics of volcanic rifted margins. Geological Society of America Special Paper 362, 1-14.

Milner, S.C., 1988. The Geology and geochemistry of the Etendeka Formation quartz latites, Namibia. Unpublished PhD thesis, University of Cape Town, 263p.

Milner, S.C., Duncan, A.R., Ewart, A. 1992. Quartz latite rheoignimbrite flows of the Etendeka Formation, north-western Namibia. Bull. Volcanol. 54, 200-219.

Milner, S.C., Duncan, A.R., Whittingham, A.M., Ewart, A., 1995. Trans-Atlantic correlation of eruptive sequences and individual silicic volcanic units within the Parana-Etendeka igneous province. J. Volcanol. Geotherm. Res. 69, 137-157. (doi:10.1016/03770273(95)00040-2).

Morton, A.C., Knox, R.W.O., 1990. Geochemistry of late Palaeocene and early Eocene tephras from the North Sea Basin. J. Geol. Soc. (Lond.) 147, 425-437.

Newhall C.G., Punongbayan, R.S. (Eds), 1996. Fire and Mud: Eruptions and Lahars of Mount Pinatubo, Philippines, University of Washington Press, Seattle, 1126 pp..

Nielsen, T.D.F., Soper, N.J., Brooks, C.K., Faller, A.M., Higgins, A.C., Matthews, D.W., 1981. The pre-basaltic sediments and the Lower Basalts at kangerlussuaq, East Greenland: their stratigraphy, lithology, paleomagnetism and petrology. Meddelelser om Grønland, Geosciences 6, 1-25.

Oppenheimer, C., 2002. Limited global change due to the largest known Quaternary eruption, Toba 74 kyr BP? Quatern. Sci. Rev. 21, 1593-1609. (doi:10.1016/S0277-3791(01)001548)

Ostenaa, D.A., O'Connell, D.R.H., Walters, R.A. and Creed, R.J., 2002. Holocene paleoflood 
hydrology of the Big Lost River, western Idaho National Engineering and Environmental Laboratory, Idaho. In: Geology, Hydrology and Environmental Remediation: Idaho National Engineering and Environmental Laboratory, Eastern Snake River Plain, Idaho (Eds P.K. Link and L.L. Mink), Geol. Soc. Am. Spec. Pap. 353, 91-110.

Pankhurst, R.J., Leat, P.T., Sruoga, P., Rapela, C.W., Márquez, M., Storey, B.C., Riley, T.R., 1998. The Chon Aike province of Patagonia and related rocks in West Antarctica: A silicic large igneous province. J. Volcanol. Geotherm. Res 81, 113-136. (doi:10.1016/S03770273(97)00070-X)

Pankhurst, R.J., Riley, T.R., Fanning, C.M., Kelley, S.P., 2000. Episodic silicic volcanism in Patagonia and the Antarctic Peninsula: chronology of magmatism associated with the break-up of Gondwana. J. Petrol. 41, 605-625.

Patterson, E.M., 1963. Tertiary vents in the northern part of the Antrim plateau, Ireland. Quart. J. Geol. Soc. London 119, 419-443.

Pedersen AK, Watt M, Watt WS, Larsen LM (1997) Structure and stratigraphy of the Early Tertiary basalts of the Blosseville Kyst, East Greenland. J. Geol. Soc. 154:565-570

Piccirillo, E.M., Bellieni, G., Cavazzini, G., Comin-Chiaramonti, P., Petrini, R., Melfi, A.J., Pinese, J.P.P., Zantedeschi, P., De-Min, A., 1990. Lower Cretaceous tholeiitic dyke swarms from the Ponta Grossa Arch (Southeast Brazil); petrology, Sr-Nd isotopes and genetic relationships with the Parana flood volcanics. Chem. Geol. 89, 19-48.

Planke, S., Symonds, P.A., Alvestad, E., Skogseid, J., 2000. Seismic volcanostratigraphy of large-volume basaltic extrusive complexes on rifted margins. J. Geophys. Res. 105, $19,335-19,351$.

Pollard, D.D. and Johnson, A.M., 1973, Mechanics of growth of some laccolithic intrusions in the Henry Mountains, Utah, II. Tectonophysics, 18: 311-354.

Reidel and P.R. Hooper (Editors), Volcanism and tectonism in the Columbia River flood-basalt province, Special Paper of the Geological Society of America 239, Geological Society of America, Boulder, Colorado,

Reidel, S.P., Tolan, T.L., 1992. Eruption and emplacement of flood basalt; an example from the large-volume Teepee Butte Member, Columbia River Basalt Group. Geol. Soc. Am. Bull. 104, 1650-1671.

Reidel, S.P., Tolan, T.L., Beeson, M.H., Anderson, J.L., Fecht, K.R., Swanson, D., 1989. 
Revisions to the estimates of the areal extent and volume of the Columbia River Basalt Group. In: S.P. Reidel and P.R. Hooper (Editors), Volcanism and tectonism in the Columbia River flood-basalt province, Special Paper of the Geological Society of America 239, 21-21.

Reubi, O., Ross, P.-S., White, J.D.L., 2005. Debris avalanche deposits associated with Large Igneous province volcanism: an example from the Mawson Formation, Central Allan Hills, Antarctica. Geol. Soc. Am. Bull. 117, 1615-1628.

Richey, J.E., 1948. Scotland : the Tertiary volcanic districts. British regional geology. Her Majesty's Stationery Office, Edinburgh, 105 pp.

Riley, T.R., Leat, P.T., 1999. Large volume silicic volcanism along the proto-Pacific margin of Gondwana: lithological and stratigraphical investigations from the Antarctic Peninsula. Geol. Mag. 136, 1-16. (doi: 10.1017/S0016756899002265)

Riley, T.R., Leat, P.T., Pankhurst, R.J., Harris, C., 2001. Origins of large volume rhyolitic volcanism in the Antarctic Peninsula and Patagonia by crustal melting. J. Petrol. 42, 1043-1065.

Rose W.I., Chesner, C.A., 1987. Dispersal of ash in the great Toba eruption, 75ka. Geology, 15, 913-917.

Ross P-S (2005) Volcanology of the Mawson Formation at Coombs and Allan Hills, South Victoria Land, Antarctica. Unpublished PhD dissertation, Geology Department. University of Otago, Dunedin, NZ, pp 400

Ross, P.-S., White, J.D.L., 2005a. Mafic, large-volume, pyroclastic density current deposits from phreatomagmatic eruptions in the Ferrar large igneous province, Antarctica. J. Geol. 113, 627-649.

Ross, P.-S., White, J.D.L., 2005b. Unusually large clastic dykes formed by elutriation of a poorly sorted, coarser-grained source. J. Geol. Soc. (Lond.) 162, 579-582.

Ross, P.-S., White, J.D.L., 2006. Debris jets in continental phreatomagmatic volcanoes: a field study of their subterranean deposits in the Coombs Hills vent complex, Antarctica. J. Volcanol. Geotherm. 149, 62-84.

Ross, P.-S., Ukstins Peate, I., McClintock, M.K., Xu, Y.G., Skilling, I.P., White, J.D.L., Houghton, B.F., 2005. Mafic volcaniclastic deposits in flood basalt provinces: a review. J. Volcanol. Geotherm. Res. 145, 281-314. (doi:10.1016/j.jvolgeores.2005.02.003). 
Ross, P.-S., White, J.D.L., McClintock, M., 2008. Geological evolution of the Coombs-Allan Hills area, Ferrar large igneous province, Antarctica: debris avalanches, mafic pyroclastic density currents, phreatocauldrons... J. Volcanol. Geotherm. Res. in press, doi 10.1016/j.jvolgeores.2005.11.011

Rubin, A.M., 1995. Propagation of magma-filled cracks. Annual Review of Earth and Planetary Science, 23: 287-336.

Schmincke, H.-U., 1967. Fused tuff and peperites in south-central Washington. Geol. Soc. Am. Bull. 78, 319-330.

Self S, Thordarson T, Keszethelyi L, Walker GPL, Hon K, Murphy MT, Long P, Finnemore S (1996) A new model for the emplacement of Columbia River basalts as large, inflated pahoehoe lava flow fields. Geophysical Research Letters 23:2689-2692

Self, S., Thordarson, T. and Keszthelyi, L.P., 1997. Emplacement of Continental Flood Basalt Lava Flows. In: J.J. Mahoney and M.F. Coffin (Editors), Large igneous provinces; continental, oceanic, and planetary flood volcanism Geophysical Monograph 100. American Geophysical Union, Washington, DC, 381-410.

Self, S., Keszthelyi, L. and Thordarson, T., 1998. The importance of pahoehoe. Annual Review of Earth and Planetary Sciences 26, 81-110.

Self, S, Thordarson, Th, and Widdowson, M, 2005, Gas fluxes from flood basalt eruptions. Elements 1, 283-287.

Self, S., Jay, A.E., Widdowson, M., Kesthelyi, L.P., 2008. The longest and largest lava flows on Earth? J. Volcanol. Geotherm. Res in press, doi 10.1016/j.jvolgeores.2006.11.012

Sharma, K.K., 2005. The Malani magmatism: an extensional lithospheric tectonic origin. In: Foulger, G.R., Natland, J.H., Presnall, D.C., Anderson, D.L. (Eds.) Plates, Plumes and Paradigms. Geol. Soc. Am. Spec. Pap. 388, pp. 463-476.

Shipboard Scientific Party, 2001. Site 1184. In: Mahoney, J.J., Fitton, J.G., Wallace, P.J., et al., (Eds.), Proceedings of the Ocean Drilling Program. Initial Reports [CD-ROM] Leg. 92, pp. $1-131$.

Single RT, Jerram DA, 2004, The 3D facies architecture of flood basalts and their internal heterogeneity: examples from the Skye Lava filed. J geol Soc. 161, 911-926.

Smart, J., Senior, B.R., 1980. The Jurassic-Cretaceous basins of northeastern Australia. In: Henderson RA, Stephenson PJ (eds) The Geology and Geophysics of Northeastern 
Australia. Geol. Soc. Aust. QLD Div., Brisbane, pp. 315-328.

Stephenson, P.J., 1990. Some aspects of dyke emplacement and characteristics in the TownsvilleIngham District, North Queensland, Australia. In Parker A.J., Rickwood, P.C., and Tucker, D.H., eds, Mafic dykes and Emplacement Mechanisms, Proceedings of the Second International Dyke Conference: A. A. Balkema, Rotterdam-Brookfield, no. 2, pp. 421-430.

Stephenson, P.J. Burch-Johnston, A.T., Stanton, D., Whitehead, P.W. 1998. Three long lava flows in North Queensland. J. Geophys. Res. 103, 27,359-27,370.

Swanson, D.A., Wright, T.L., 1981. The regional approach to studying the Columbia River Basalt Group. In: K.V. Subbaroa and R.N. Sukheswala (Eds.), Deccan volcanism and related basalt provinces of the world. Geol. Soc. India Memoir 3, pp. 58-80.

Swanson, D.A., Wright, T.L., Helz, R.T., 1975. Linear vent systems and estimated rates of magma production and eruption for the Yakima Basalt on the Columbia Plateau. Am. J. Sci. 275, 877-905.

Swanson, E.R., McDowell, F.W., 1984. Calderas of the Sierra Madre Occidental volcanic field, western Mexico. J. Geophys. Res. 89, 8787-8799.

Swanson, E.R., McDowell, F.W., 2000. Sierra Madre Occidental volcanic field; a history of field studies. Abstracts with Programs - Geological Society of America, 32, 467-468.

Swanson, E.R., Kempter, K.A., McDowell, F.W., McIntosh, W.C., 2006. Major ignimbrites and volcanic centers of the Copper Canyon area; a view into the core of Mexico's Sierra Madre Occidental. Geosphere 2, 125-141.

Tegner, C. et al., 1998. $\mathrm{Ar}^{40}-\mathrm{Ar}^{39}$ Geochronology Of Tertiary Mafic Intrusions Along the East Greenland Rifted Margin - Relation to Flood Basalts and the Iceland Hotspot Track. Earth and Planetary Science Letters, 156: 75- 88.

Thomson, K. and Hutton, D., 2004, Geometry and growth of sill complexes: insights using 3D seismic from the North Rockall trough: Bulletin of Volcanology 66, 364-375.

Thordarson T (1995) Volatile release and atmospheric effects of basaltic fissure eruptions. Unpublished PhD dissertation, Department of Geology and Geophysics. University of Hawaii, Honolulu, pp 570

Thordarson, T., 2004. Accretionary-lapilli-bearing pyroclastic rocks at ODP Leg 192 Site 1184: a record of subaerial phreatomagmatic eruptions on the Ontong Java Plateau. In: J.G. Fitton, J.J. Mahoney, P.J. Wallace and A.D. Saunders (Eds.), Origin and evolution of the Ontong 
Java Plateau. Geol. Soc. Special Pub. 229, pp. 275-306.

Thordarson, T., Self, S., 1996. Sulfur, chlorine, and fluorine degassing and atmospheric loading by the Roza eruption, Columbia River Basalt Group, Washington, USA. J. Volcanol. Geotherm. Res. 74, 49-73. (doi:10.1016/S0377-0273(96)00054-6)

Thordarson, T. and Self, S., 1998. The Roza Member, Columbia River Basalt Group; a gigantic pahoehoe lava flow field formed by endogenous processes? Journal of Geophysical Research, B, Solid Earth and Planets 103 (11), 27,411-27,445.

Thordarson, T., Self, S., Óskarsson, N., Hulsebosch, T., 1996. Sulfur, chlorine, and fluorine degassing and atmospheric loading by the 1783-1784 AD Laki (Skaftár Fires) eruption in Iceland. Bull. Volcanol. 58, 205-225.

Thorne, A.M., Trendall, A.F., 2001. Geology of the Fortescue Group, Pilbara Craton, Western Australia. Bull. - Geol. Surv. West. Aust. 144, 249p.

Touchard, Y., Rochette, P., Aubry, M.P., Michard, A., 2003. High-resolution magnetostratigraphic and biostratigraphic study of Ethiopian traps-related products in Oligocene sediments from the Indian Ocean. Earth Planet. Sci. Lett. 206, 493-508. (doi:10.1016/S0012-821X(02)01084-1)

Tolan, T.L., Reidel, S.P., Beeson, M.H., Anderson, J.L., Fecht, K.R. and Swanson, D., 1989. Revisions to the estimates of the areal extent and volume of the Columbia River Flood Basalt Province. In: S.P. Reidel and P.R. Hooper (Editors), Special Paper of the Geological Society of America 2839, 1-20.

Touchard, Y., Rochette, P., Hamelin, B., Michard, A., 2003b. Long distance transport of glass shards from Ethiopian Traps megaplinian eruption [abstract]. IUGG 2003, Sapporo, Japan, abstract book, p. A204.

Twist, D., French, B.M., 1983. Voluminous acid volcanism in the Bushveld Complex: a review of the Rooiberg Felsite. Bull. Volcanol. 46, 225-242.

Ukstins Peate, I.A., 2002. Volcanostratigraphy, geochemistry and geochronology of silicic volcanism in the Afro-Arabian flood volcanic province (Yemen and Ethiopia). Unpublished Ph.D. thesis, Royal Holloway University of London, UK, 413p.

Ukstins Peate, I., Larsen, M., Lesher, C.E., 2003a. The transition from sedimentation to flood volcanism in the Kangerlussuaq Basin, East Greenland: basaltic pyroclastic volcanism during initial Palaeogene continental break-up. J. Geol. Soc. (Lond.) 160, 759-772. 
Ukstins Peate, I., Baker, J.A., Kent, A.J.R., Al-Kadasi, M., Al-Subbary, A., Ayalew, D., Menzies, M., 2003b. Correlation of Indian Ocean tephra to individual Oligocene silicic eruptions from Afro-Arabian flood volcanism. Earth Planet. Sci. Lett. 211, 311-327. (doi:10.1016/S0012-821X(03)00192-4).

Ukstins Peate, I., Baker, J.A., Al-Kadasi, M., Al-Subbary, A., Knight, K.B., Riisager, P., Thirlwall, M.F., Peate, D.W., Renne, P.R., Menzies, M.A., 2005. Volcanic stratigraphy of large-volume silicic pyroclastic eruptions during Oligocene Afro-Arabian flood volcanism in Yemen. Bull. Volcanol., doi:10.1007/s00445-005-0428-4)

Ukstins Peate, I., Kent, A.J.R., Baker, J.A., Menzies, M.A., 2007. Extreme geochemical heterogeneity in Afro-Arabian Oligocene tephras: Preserving fractional crystallization and mafic recharge processes in large-volume silicic magma chambers. Lithos (in press).

Viswanathan, S., Chandrasekharam, D., 1981. Geochemical comparison of the Siberian and Deccan Traps. In: K.V. Subbaroa and R.N. Sukheswala (Eds.), Deccan volcanism and related basalt provinces of the world. Geol. Soc. India Memoir 3, pp. 460-471.

von Rad, U., Thurow, J., 1992. Bentonitic clays as indicators of Early Neocomian post-breakup volcanism off northwest Australia. Proc. Ocean Drilling Prog., Scientific Results, 122, 213-232.

Walker, G.P.L., 1983. Ignimbrite types and ignimbrite problems. J. Volcanol. Geotherm. Res. 17, 65-88.

Walker, G.P.L., 1969, Some observations and interpretations on the Deccan Traps. Recently published in: Subbarao KV (Ed) Deccan Volcanic Province: Mem Geol Soc India 43 $1: 367-395$

Walker, G.P.L., 1972, Compound and simple lava flows and flood basalts. Bull Volcanol 35 : 579-590.

Walker, G.P.L., 1993. Basaltic-volcano systems. In: H.M. Prichard, T. Alabaster, N.B.W. Harris and C.R. Neary (Editors), Magmatic Processes and Plate Tectonics. Geological Society of London, Special Publication 76, London, pp. 3-38.

Walker, G.P.L., 1995 Flood basalts versus central volcanoes and the British Tertiary Volcanic Province. In Le Bas, M.J. (ed.) Milestones in Geology. Geological Society London Memoir 116, pp. 195-202. . 
Walker, G.P.L., 1999. Some observations and interpretations on the Deccan Traps. In: K.V. Subbarao (ed) Deccan Volcanic Province, Geological Society of India, Bangalore, 43 (1) 367-395.

Ward, P.L., 1995. Subduction cycles under western North America during the Mesozoic and Cenozoic eras. In: Miller D.M., Busby C. (eds), Jurassic Magmatism and Tectonics of the North American Cordillera. Geol. Soc. Am. Spec. Pap. 299, 1-45.

Wark, D.A., 1991. Oligocene ash flow volcanism, northern Sierra Madre Occidental: Role of mafic and intermediate-composition magmas in rhyolite genesis. J. Geophys. Res. 96, $13,389-13,411$.

Welhan, J.A. and Reed, M.F., 1997, Geostatistical Analysis Of Regional Hydraulic Conductivity variations in the Snake River Plain Aquifer, Eastern Idaho. Geol. Soc. Am. Bull. 109, 855868.

Wood, C. and Watts, R, 2002, Laki underground 2001: Bournemouth UK, School of Conservation Sciences, Bournmouth University, $32 \mathrm{p}$.

White, J.D.L., Garland, M.J., 2007. Shoaling sills of a Large Igneous Province: sills and dikes at Coombs Hills, Ferrar Province, Antarctica. Geophysical Research Abstracts 9, EGU2007A-06221; GMPV7-1WE4O-006

White, J.D.L., McClintock, M.K., 2001. Immense vent complex marks flood-basalt eruption in a wet, failed rift: Coombs Hills, Antarctica. Geology 29, 935-938. (doi: 10.1130/00917613(2001)029<0935:IVCMFB >2.0.CO;2)

White, J.D.L., Houghton, B.F., 2006. Primary volcaniclastic rocks. Geology 34, 677-680.

White, J.D.L., McPhie, J., and Skilling, I., 2000. Peperite: a useful genetic term: Bulletin of Volcanology 62, 65-66.

White, J.D.L., Thordarson, T., McClintock, M.K. and Ross, P.S., 2005. Cracking the Lid - Dike Emplacement Above Large Sills of the Ferrar Province, Antarctica. Eos, 86((52) Fall Meet. Suppl.): Abstract V23A-0690.

White, J.D.L., Ross, P.-S., McClintock, M.K., Reubi, O. and Thordarson, T. 2006. Not the usual fissure? Explosive eruptions, country-rock avalanches and sill-lid breakup in the Ferrar Large Igneous Province, South Victoria Land, Antarctica. Abstract, IAVCEI George P.L. Walker symposium on advances in volcanology, Reykholt, Iceland, $\mathrm{p} 18$. \{http://www.iavcei.org/Norvol_lokaprogram.pdf 
Widdowson, M., Walsh, J.N., Subbarao, K.V., 1997. The geochemistry of Indian bole horizons; palaeoenvironmental implications of Deccan intravolcanic palaeosurfaces. In: M. Widdowson (Ed.), Palaeosurfaces; recognition, reconstruction and palaeoenvironmental interpretation. Geol. Soc. Special Pub. 120, pp. 269-281.

Wignall, P.B., 2001. Large igneous provinces and mass extinctions. Earth-Sci. Rev. 53, 1-33.

Williams, H., McBirney, A.R., 1979. Volcanology. Freeman, Cooper and Co, San Francisco Publ., Berkeley, CA, 397 pp.

Wilson, C.J.N., Hildreth, W., 1997. The Bishop Tuff: new insights from eruptive stratigraphy. J. Geol. 105, 407-439.

Wilson, C.J.N., Houghton, B.F., McWilliams, M.O., Lanphere, M.A., Weaver, S.D., Briggs, R.D., 1995. Volcanic and structural evolution of Taupo Volcanic Zone, New Zealand: A review. J. Volcanol. Geotherm. Res. 68, 1-28. (doi:10.1016/0377-0273(95)00006-G).

Wilson, L. and Head, J.W., 2002. Tharsis-radial graben systems as the surface manifestation of plume-related dike intrusion complexes: Models and implications. Journal of Geophysical Research-Planets, 107(E8), Art. No. 5000 Aug 1.

Wilson, T.J., 1993. Jurassic faulting and magmatism in the Transantarctic Mountains: implications for Gondwana breakup. In: R.H. Findlay, R. Unrug, M.R. Banks and J.J. Veevers (Editors), Gondwana Eight: assembly, evolution and dispersal. Balkema, Rotterdam, pp. 563-572.

Xu, Y-G., He, B., Chung, S-L., Menzies, M.A., Frey, F.A., 2003. Geologic, geochemical, and geophysical consequences of plume involvement in the Emeishan flood-basalt province. Geology 32, 917-920. 
Table 1. Summary of mafic volcaniclastic deposits from Phanerozoic mafic LIPs (continental flood basalt provinces except the Ontong Java), after Ross et al. (2005) and references therein

\begin{tabular}{|c|c|}
\hline Province & Features \\
\hline $\begin{array}{l}\text { Columbia } \\
\text { River Basalts }\end{array}$ & $\begin{array}{l}\text { - } \quad \text { possible phreatomagmatic vent infills (Fuller, 1928) } \\
\text { pillow-palagonite complexes, common at base of lava flows, especially near plateau margins (Swanson } \\
\text { and Wright, 1981) } \\
\text { - } \quad \text { proximal pyroclastic accumulations near linear vents (Swanson et al., 1975; Thordarson and Self, 1996) }\end{array}$ \\
\hline Afro-Arabia & $\begin{array}{l}\text { - } \quad \text { mafic mega-breccia in upper part of sequence in Yemen (Ukstins Peate et al., 2005) } \\
\text { - } \quad \text { primary deposits intercatated with earliest lavas in Ethiopia and Yemen } \\
\text { mafic volcaniclastic deposits overlying basement in NE Yemen Plateau }\end{array}$ \\
\hline Deccan Traps & $\begin{array}{l}\text { - fine-grained mafic material in clastic layers between flood lavas ('intertrappean' beds; e.g., Widdowson, et } \\
\text { al., 1997); } \\
\text { - } \quad \text { both fine \& coarse mafic volcaniclastic deposits reported from base of lava sequence in Mumbai region } \\
\text { thick late Cretaceous deposits in Pakistan (Khan et al., 1999) }\end{array}$ \\
\hline $\begin{array}{l}\text { North Atlantic } \\
\text { Igneous }\end{array}$ & $\begin{array}{l}\text { East Greenland: near the coast, mafic volcaniclastic deposits constitute } 35-50 \% \text { of the lower volcanics, } \\
\text { much less in the overlying plateau lavas (Ukstins Peate et al., 2003a) }\end{array}$ \\
\hline Province & $\begin{array}{l}\text { - Faeroe Islands: over } 1100 \text { m of mafic volcaniclastic deposits underneath the flood lavas in one drill hole } \\
\text { (Ellis et al., 2002) } \\
\text { North Sea and Denmark: over } 130 \text { basaltic tephra layers intercalated in sediments of the Balder Formation } \\
\text { and correlatives (Larsen et al., 2003), possibly causing early Eocene cooling (Jolley and Widdowson, } \\
\text { 2005) } \\
\text { Ireland: numerous exposures of vent-filling breccia containing basaltic clasts near the Giant's Causeway } \\
\text { (Patterson, 1963) } \\
\text { - several other occurrences in other areas }\end{array}$ \\
\hline Ontong Java & $\begin{array}{l}\text { - over } 300 \mathrm{~m} \text { of mafic volcaniclastic deposits, rich in accretionary lapilli, occur in one drill hole without any } \\
\text { overlying lavas (Thordarson, 2004) }\end{array}$ \\
\hline Ferrar & $\begin{array}{l}\text { - flood lavas are almost everywhere underlain by mafic volcaniclastic deposits ranging in exposed thickness } \\
\text { from } 10 \mathrm{~m} \text { to over } 400 \mathrm{~m} \text {, interpreted as phreatomagmatic deposits (Elliot and Fleming, 2008) } \\
\text { overall mafic volcaniclastic deposits are dominated by poorly sorted, structureless to diffusely-layered } \\
\text { tuff-breccias and coarse lapilli-tuffs, with subordinate tuffs and fine lapilli-tuffs } \\
\text { - } \quad \text { interesting features include tuff ring remnants (Ross et al., in press), debris avalanche deposits (Reubi et } \\
\text { al., 2005), huge clastic dikes (Ross and White, 2005b), and thick mafic pyroclastic flow deposits (Ross et } \\
\text { al., 2005a) } \\
\text { among the coarser-grained rocks, some are filling diatreme-like vents or vent complexes (White and } \\
\text { McClintock, 2001; Ross and White, 2006), whereas other form layers filling pre-existing topographic } \\
\text { depressions (Ross and White, 2005a; McClintock and White, 2006) }\end{array}$ \\
\hline Karoo & $\begin{array}{l}\text { - mafic volcaniclastic deposits exposed locally within an area about } 530 \text { by } 240 \mathrm{~km} \text { in Lesotho and South } \\
\text { Africa, underneath the main flood lavas (Du Toit, 1954) } \\
\text { includes thickly bedded to structureless, mainly coarse-grained mafic volcaniclastic deposits, } 100-250+\mathrm{m} \\
\text { thick, within steep-walled depressions }\left(5-40+\mathrm{km}^{2}\right) \text { in pre-existing country rock; these centres are } \\
\text { surrounded by sheets of thinner-bedded, mainly lapilli and ash-grade deposits, } 10-100 \mathrm{~m} \text { thick (e.g., } \\
\text { McClintock et al., 2008) }\end{array}$ \\
\hline Siberian Traps & $\begin{array}{l}\text { - mafic volcaniclastic deposits are thought to represent about a quarter of the total volume of the province } \\
\text { on the Siberian platform (Viswanathan and Chandrasekharam, 1981) } \\
\text { the thickest volcaniclastic accumulations (up to } 700 \mathrm{~m} \text { ) are older than the lavas } \\
\text { in the Noril'sk area, some mafic volcaniclastic layers (including agglomerates) are up to } 100 \mathrm{~m} \text { thick, and } \\
\text { a } 15-25 \mathrm{~m} \text {-thick layer can be traced over } 30,000 \mathrm{~km}^{2} \text { (Czamanske et al., 1998) }\end{array}$ \\
\hline Emeishan & $\begin{array}{l}\text { - mafic volcaniclastic deposits and sedimentary rocks containing mafic lava fragments are relatively } \\
\text { widespread but their volume probably represents }<10 \% \text { of the province } \\
\text { - } \quad \text { mafic volcaniclastic deposits up to } 170 \mathrm{~m} \text { thick with a potential distribution of } 400 \text { by } 30-70 \mathrm{~km} \\
\text { occur in the lower parts of the stratigraphy and dominated by thick bedded, limestone \& basalt block- } \\
\text { bearing tuff breccias interbedded with lavas and accretionary lapilli tuffs }\end{array}$ \\
\hline
\end{tabular}


Table 2. A comparison and rating of the variety of primary fragmentation processes, and the importance of reworking to produce volcaniclastic rocks in LIPs. NAIP: North Atlantic Igneous Province.

\begin{tabular}{|c|c|c|}
\hline Process & Mafic LIPs & Silicic LIPs \\
\hline 'Magmatic' fragmentation & $\begin{array}{l}\text { Minor process for basaltic magmas } \\
\text { producing mostly near-vent deposits (e.g., } \\
\text { spatter ramparts/cones and scoria } \\
\text { cones/fall deposits). Dominant process } \\
\text { for silicic magmas }\end{array}$ & $\begin{array}{l}\text { Dominant primary process producing } \\
\text { widespread ignimbrites, Plinian } \\
\text { fallout and co-ignimbrite tuffs }\end{array}$ \\
\hline $\begin{array}{l}\text { Phreatomagmatic } \\
\text { fragmentation }\end{array}$ & $\begin{array}{l}\text { Significant for continental flood basalts } \\
\text { emplaced through pre-existing hydrologic } \\
\text { reservoirs or where developing rifts are } \\
\text { flooded (e.g., NAIP); mafic magma } \\
\text { interaction with groundwater in } \\
\text { sedimentary aquifers; minor to rare for } \\
\text { silicic magmas }\end{array}$ & $\begin{array}{l}\text { Significant, especially in flooded } \\
\text { caldera and rift valley environments; } \\
\text { magma interaction mainly with } \\
\text { surface water (i.e. lakes) }\end{array}$ \\
\hline Autoclastic fragmentation & $\begin{array}{l}\text { Dominant primary process fragmenting } \\
\text { basaltic lava flows; minor for silicic } \\
\text { rheoignimbrites }\end{array}$ & $\begin{array}{l}\text { Minor to rare, affecting lavas of all } \\
\text { composition (basalt to rhyolite) }\end{array}$ \\
\hline Hyaloclastite formation & $\begin{array}{l}\text { Minor process in subaerial LIPs; likely to } \\
\text { be more significant for subaqueously- } \\
\text { emplaced LIPs (e.g., oceanic plateaux, } \\
\text { submarine ridges, seamounts) }\end{array}$ & $\begin{array}{l}\text { Minor process generally affecting } \\
\text { lavas emplaced into hydrologic } \\
\text { reservoirs (e.g., lakes, rivers) }\end{array}$ \\
\hline $\begin{array}{l}\text { Reworking and } \\
\text { resedimentation }\end{array}$ & $\begin{array}{l}\text { Minor process in provinces consisting of } \\
\text { largely coherent mass of unfragmented } \\
\text { lava; becomes more significant where } \\
\text { mafic phreatomagmatic and silicic } \\
\text { pyroclastic deposits (nonwelded) present }\end{array}$ & $\begin{array}{l}\text { Important; substantial remobilisation } \\
\text { of the primary silicic volcaniclastic } \\
\text { deposits }\end{array}$ \\
\hline
\end{tabular}


Table 3. Comparison between caldera-forming (silicic) ignimbrite eruptions and explosive mafic eruptions in LIPs.

\begin{tabular}{|c|c|c|}
\hline Feature & $\begin{array}{l}\text { Caldera-forming (silicic) ignimbrite } \\
\text { eruptions in LIPs }\end{array}$ & Explosive mafic eruptions in LIPs \\
\hline $\begin{array}{l}\text { Dominant fragmentation } \\
\text { mechanism }\end{array}$ & $\begin{array}{l}\text { 'Magmatic' explosive fragmentation of } \\
\text { viscous and vesiculated magma }\end{array}$ & $\begin{array}{l}\text { Phreatomagmatic, driven by explosive } \\
\text { interaction of magma with external } \\
\text { water }\end{array}$ \\
\hline $\begin{array}{l}\text { Pre-welding/compaction } \\
\text { vesicularity of juvenile clasts }\end{array}$ & $\begin{array}{l}\text { Mostly high, moderate to low for } \\
\text { rheoignimbrites of CFBPs }\end{array}$ & $\begin{array}{l}\text { Variable but mostly low (Ross et al., } \\
\text { 2005) }\end{array}$ \\
\hline $\begin{array}{l}\text { Dominant transport } \\
\text { mechanism }\end{array}$ & Pyroclastic density currents & Varied (see text) \\
\hline Eruption rates & Very high ${ }^{1}$ & Varied \\
\hline Recurrence & $\begin{array}{l}\text { Low }\left(10^{3}-10^{5} \text { yrs }\right) \text { but probably higher } \\
\text { during main eruptive phase }(\mathrm{s})\end{array}$ & Relatively high? \\
\hline Eruption duration & $\begin{array}{l}\text { Cataclysmic eruptions, hours/days to } \\
\text { weeks }^{2}\end{array}$ & $\begin{array}{l}\text { Several eruptions over many years? } \\
\text { (Ross, 2005) }\end{array}$ \\
\hline Eruption plumes & Subplinian to ultraplinian & Small to ultraplinian? \\
\hline $\begin{array}{l}\text { Sulphur concentration in } \\
\text { magmas }\end{array}$ & $\begin{array}{l}\text { Unknown, dissolved concentrations in } \\
\text { magmas less than basalt but 'excess } \\
\text { sulphur' budgets potentially substantial, } \\
\text { especially via basaltic underplating }\end{array}$ & $\begin{array}{l}\text { High (e.g., Thordarson and Self, 1996; } \\
\text { Thordarson et al., 1996) }\end{array}$ \\
\hline $\begin{array}{l}\text { Potential for environmental } \\
\text { impacts }\end{array}$ & $\begin{array}{l}\text { High; largest known eruptions have } \\
\text { areal extents }>10^{5} \mathrm{~km}^{2} ; \text { stratospheric } \\
\text { injections of ash and aerosols would } \\
\text { produce at least short-term climatic } \\
\text { impacts; highest impact for eruptions at } \\
\text { low latitudes }{ }^{3}\end{array}$ & $\begin{array}{l}\text { Good if there is a cumulative effect } \\
\text { from several consecutive eruptions (e.g., } \\
\text { Jolley and Widdowson, 2005) }\end{array}$ \\
\hline Volcanic depressions & $\begin{array}{l}\text { Large calderas and nested caldera } \\
\text { complexes formed by vertical collapse } \\
\text { following rapid evacuation of magma } \\
\text { chambers; volcanotectonic depressions } \\
\text { with subsidence } \pm \text { eruption foci } \\
\text { controlled by regional tectonic structures }\end{array}$ & $\begin{array}{l}\text { 'Phreatocauldrons' (White and } \\
\text { McClintock, 2001) formed } \\
\text { progressively through vent migration } \\
\text { and coalescence, plus lateral quarrying; } \\
\text { no boundary faults or massive } \\
\text { subsidence }\end{array}$ \\
\hline
\end{tabular}

1. As an analogy, the Toba $74 \mathrm{ka}$ "supereruption" mean eruption rate was $\sim 7$ x 10 $10^{9} \mathrm{~kg} / \mathrm{s}$ (Oppenheimer, 2002).

2. Large-volume silicic pyroclastic units deposited in hours: e.g., the Bishop Tuff (Wilson and Hildreth, 1997).

3. Long duration of silicic LIP volcanism will also contribute to environmental effects (see also Bryan, 2007).

4. Phreatocauldrons do not fit the current definition of caldera: "A volcanic structure, generally large, which is principally the result of collapse or subsidence into the top of a magma chamber during or immediately following eruptive activity" (Cole et al., 2005). 


\section{Figure Captions}

Figure 1. Different styles of long-distance magma transport considered by Elliot and Fleming (2004; diagram redrawn from their fig.7) for the distribution of Weddell Sea-derived magmas throughout the Ferrar LIP. In the top two cartoons, magma feeding the Ferrar Dolerite, exposed in the Transantarctic Mountains, is provided by sills extending cratonward from a megadike farther toward an outboard convergent margin, whereas in the lower cartoon the main transport is in a megadike or dike complex beneath the current outcrop belt, with delivery toward the surface by vertical diking.

Figure 2. Illustration of regional and local patterns of intrusion in the Karoo LIP, redrawn after Chevallier and Woodford (1999). The intruded strata are predominantly mudrock and minor sandstone of the lower Beaufort Group (Johnson et al., 1996), and were probably intruded at depths of several kilometres below the pre-flood basalt surface. The single cyan contour line encloses outcrops of the Stormberg lavas, and dikes mapped there are exposed within the flood-basalt sequence. The enlargement of the boxed area shows in more detail the outcrop pattern and the abundance of sills (thick curved lines), many of which form broadly dishshaped structures. Note that the abundant linear dikes in the simplified regional illustration are not apparent at this scale (drawn from 1:50,000 maps), which instead displays many curved and irregular dykes with only weak, segmented, linearity. The regional map showing rectilinear dykes demonstrates well the extent and intensity of subvolcanic intrusion, but fails to capture the chaotic and irregular pattern of intrusion apparent at larger mapping scales.

Figure 3. Simplified stratigraphic column for South Victoria Land, Ferrar LIP (right) shows approximate stratigraphic levels of dike and sill outcrops shown. In outcrops shown, dark rock is dolerite, country rock is pale sandstone. (a) Terra Cotta Mountain, $\sim 800 \mathrm{~m}$ topography, with basement exposed below sill at lower right, and (b) Mt Gran, cliff height $\sim 400 \mathrm{~m}$, with apparent transition from large sill at left to central mega-dike; inclined sheets extend from the mega-dyke, and thinner sills are exposed to the right. "CH" indicates stratigraphic range of outcrops of Coombs Hills (Figure 4). Column after McClintock (2001), Elliot (1992), Collinson et al. (1983), and Ballance (1977). 
Figure 4. (a) Northern Coombs Hills. Note large, variably tilted, blocks of sandstone enclosed in dolerite; $200 \mathrm{~m}$ relief in image. The Coombs Hills outcrops are adjacent to a large vent complex (see Ross et al., 2008 and references therein). (b) Detail of dolerite-sandstone relationships illustrated in (a). Numerous dikes and inclined sheets, some dipping at very low angles, penetrate and separate bodies of sandstone that are tilted in varying directions from their in situ orientations. The sandstone bodies at this level ( $\sim 200 \mathrm{~m}$ below nearby base of Ferrar Group flood-basalt lavas) are also penetrated by scores of thin, sinuous dikes that commonly terminate within the sediment as thin pointed tips a few millimetres wide. The dolerite cliff in shadow is the edge of a sill; its contacts against bodies of country rock to the left are subvertical, but it has distinct subhorizontal internal boundaries defined by weathering and, locally, thin lenses of country rock.

Figure 5. A four-stage diagram illustrating emplacement of lava by lobes and lobe-breakouts.

Figure 6. A composite graphic log showing illustrating characteristic structures of Roza sheet lobes Left side shows the characteristic three-part division of sheet lobes (A) and jointing styles (B). Right side of the column shows distribution of vesiculation structures (C), vesiculation (D), and degree of crystallinity (E). The scale $\mathrm{h} / \mathrm{l}$ indicates normalised height above the base of the sheet lobe (h, height in lobe; 1 , total lobe thickness). The structures in column $\mathrm{C}$ are $\mathrm{BZ}=$ basal vesicular zone, $\mathrm{PV}=$ pipe vesicles, $\mathrm{SV}=$ sheet vesicles, $\mathrm{VC}=$ vesicle cylindersScale on column D is $\mathrm{d}$, dense (0-5 vol\% vesicles); $\mathrm{m}$, moderately vesicular (10-20 vol\%); and v, vesicular (30-40 vol\%). On Column E, h, hyaline; hy, hypohyaline; hc, hypocrystalline; c, holocrystalline.

Figure 7 Two photos of "Hawaii-size" Deccan pahoehoe lobes, Bushe Formation, Lonavala Subgroup, near Poladpur, India. Top: base of a decimetre-thick lobe with pipe-vesicles - pen for scale; Bottom: small lobe with ropes, lenscap for scale.

Figure 8 (a) Schematic illustration showing the stratigraphy of the near-vent successions produced by a single eruption episode during the Laki and Eldgjá eruptions. The diagram is unscaled, but spatter ramparts are metres to a few tens of metres in scale, typical scoria cone 
crater widths and heights are a few hundred metres or less, and tephra fall deposits of significant thickness extend only a few km from the vent. (b) Exposure of near-vent Roza eruption products at Winona, Washington, consisting of a scoria-fall mound or rampart overlain by agglutinated spatter-fall facies (person for scale).

Figure 9. Schematic illustration summarizing the different positions that mafic volcaniclastic deposits (MVDs) can occupy in flood basalt provinces. NAIP $=$ North Atlantic Igneous Province. Modified from Ross et al. (2005).

Figure 10. Simplified map (a) and summary stratigraphic sections (b) of the Siberian Traps (modified from Ross et al., 2005). On the Siberian Platform, the area covered by mafic volcaniclastic deposits (MVDs) only, without flood lavas, is equivalent to that covered by flood lavas plus MVDs. Circled numbers indicate the general location of stratigraphic sections. River names in italics.

Figure 11. Illustration of mafic volcaniclastic deposits and associated features in a phreatomagmatic vent complex at Coombs Hills, Ferrar LIP (after Ross, 2005). (a) The dominant volcaniclastic rock filling the vent complex is a heterolithic lapilli-tuff containing $\mathbf{1}$. Beacon sandstone clasts, 2. coal clasts (in black, above the numbers), 3. basaltic fragments of various shapes. Unlabelled Beacon (country rock) fragments are pale to white, unlabelled basaltic fragments are in medium and dark shades. Scale bar in cm. (b) A fragment of medium to coarse sandstone with dark laminae in the heterolithic vent fill. (c) View from above of a pipe of country rock-rich lapilli-tuff cross-cutting the dominant vent fill. It has been inferred that such pipes were generated by vertically travelling "debris jets" above explosion sites (Ross and White, 2006). (d) Rafts of quartz-rich sandstone from the Beacon Supergroup, up to hundred of metres in length, "float" inside non-bedded volcaniclastic rock in the Coombs Hills phreatocauldron. The sandstone in the raft was wet and poorly consolidated during volcanism, so the rafts interacted with the basaltic magma (B), creating basalt-sandstone peperite (P) near the raft margins. (e) Sub-vertical, $>2$ m-wide basaltic dike (right of person) invading tuff-breccias. Note columnar joints perpendicular to the dike wall. Such dikes, 
and/or cylindrical plugs of basalt cross-cutting the volcaniclastic rocks, could have served as feeders for the flood lavas higher up in the sequence. (f) Dikes filled by tuff (clastic dikes), including this $12 \mathrm{~m}$-wide example, cross-cut the vent filling deposits (see Ross and White, $2005 \mathrm{~b}$ for details).

Figure 12. Generalised composite stratigraphic sections comparing the Afro-Arabian continental flood basalt provinces with the Whitsunday Silicic LIP. Lavas and volcaniclastic rocks are shown at arbitrary thicknesses on the $\mathrm{x}$-axis to emphasise distinction in rock types; dykes, sills and other intrusions are not shown. The Yemen section of the Tertiary Afro-Arabian continental „2ood basalt province, based on Baker et al. (1996) and Ukstins Peate et al. (2005); the section for the Early Cretaceous Whistunday Silicic LIP, based on Bryan et al. (2000), with the base to section not exposed (BNE). Note the similar trend in both LIP sections towards bimodal volcanism characterising the upper parts of the preserved stratigraphies (See also Bryan, 2007). 


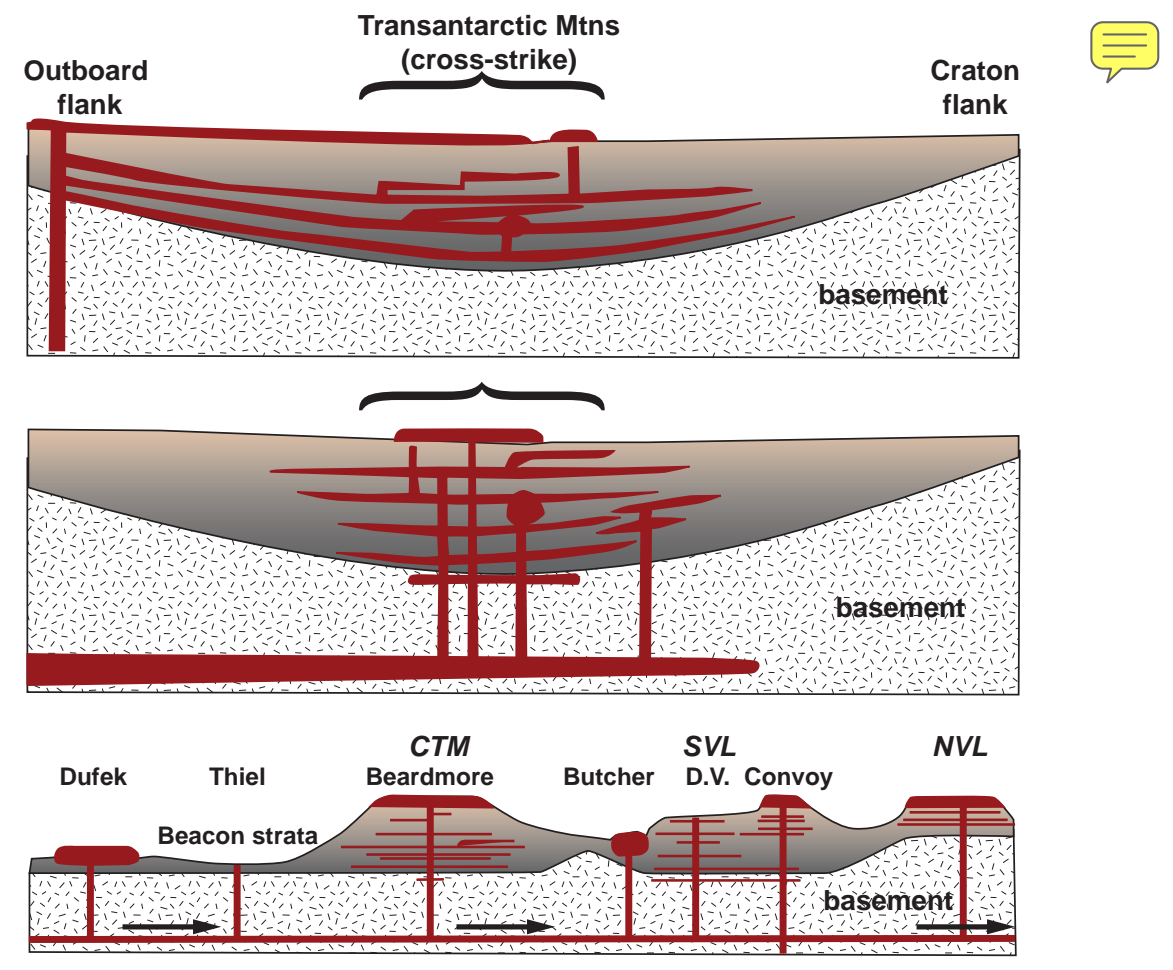



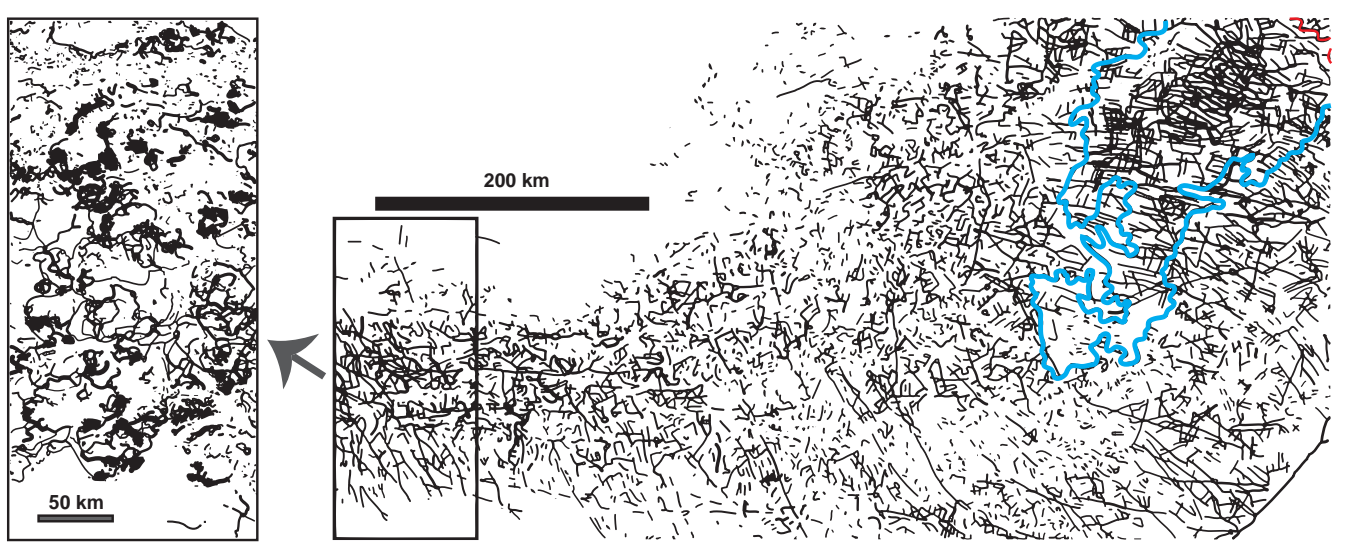

Figure 2 


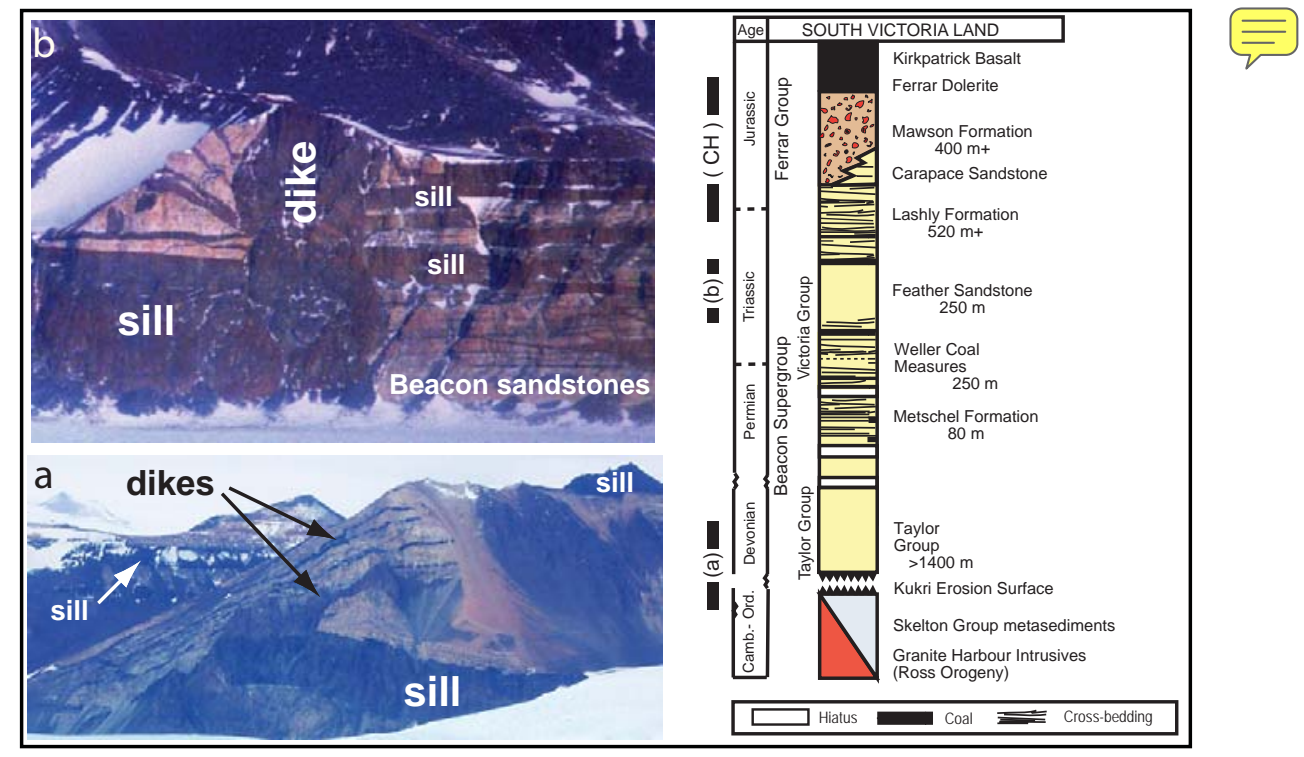




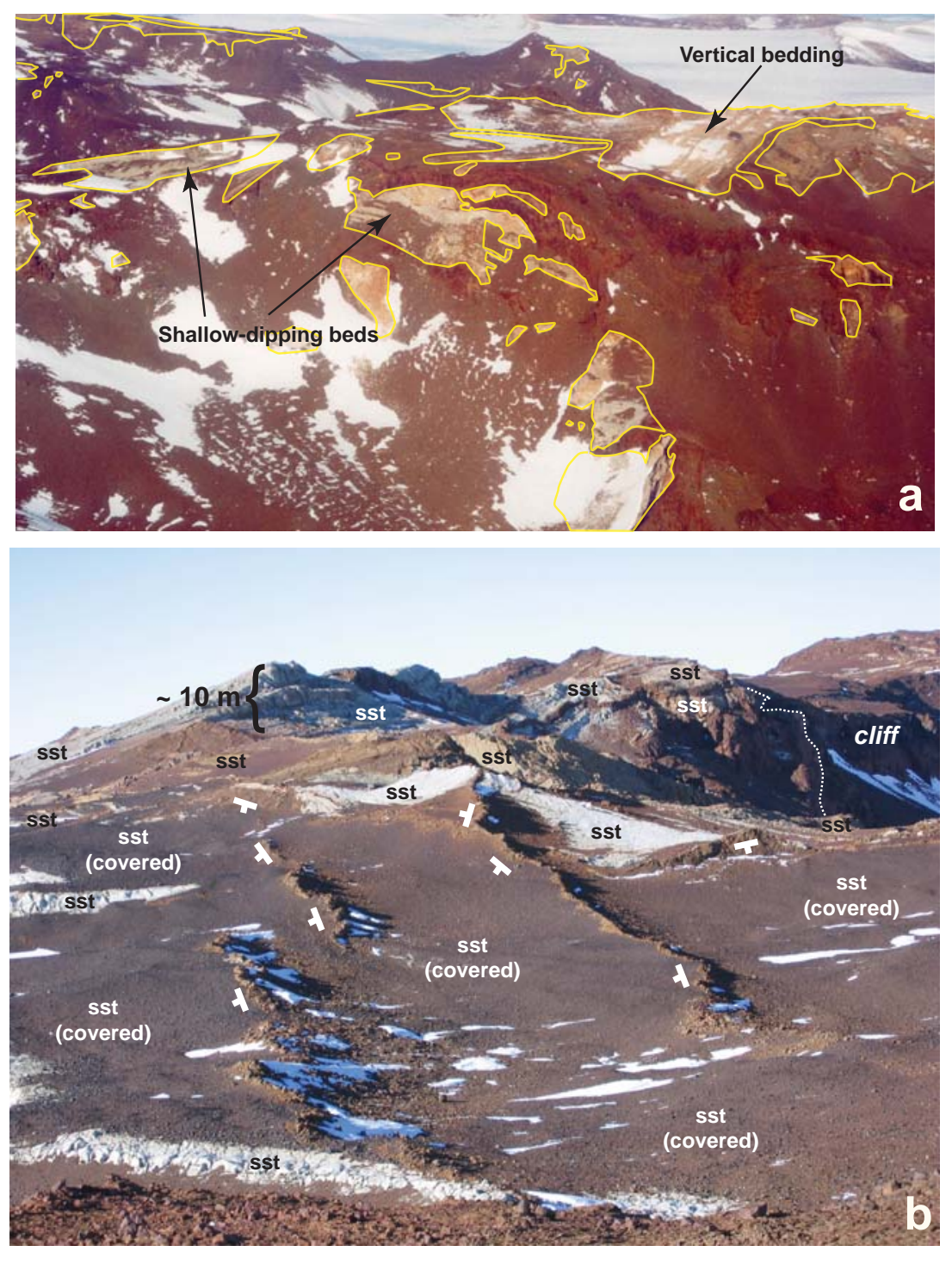

$\overline{\overline{\bar{F}}}$ 


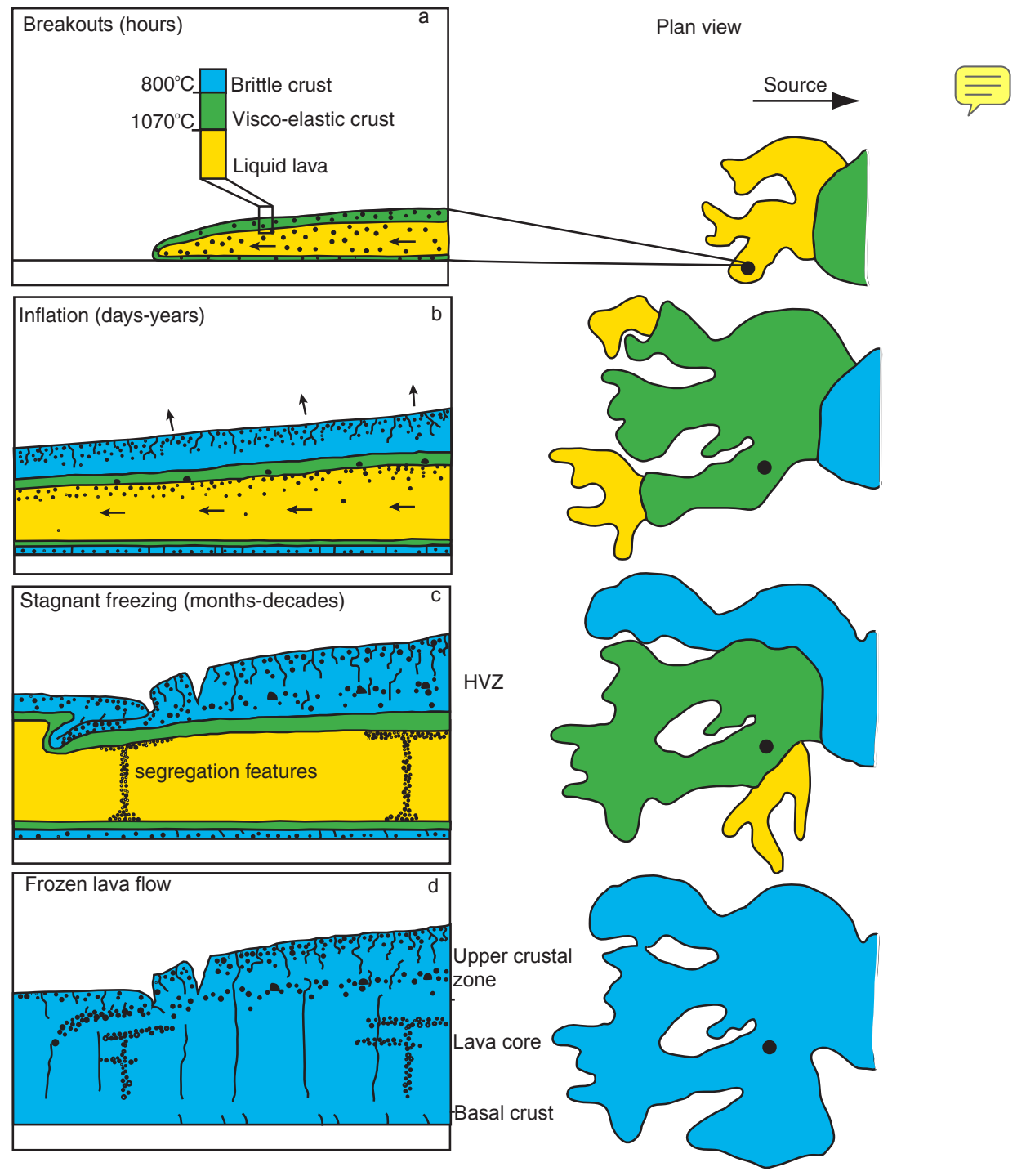




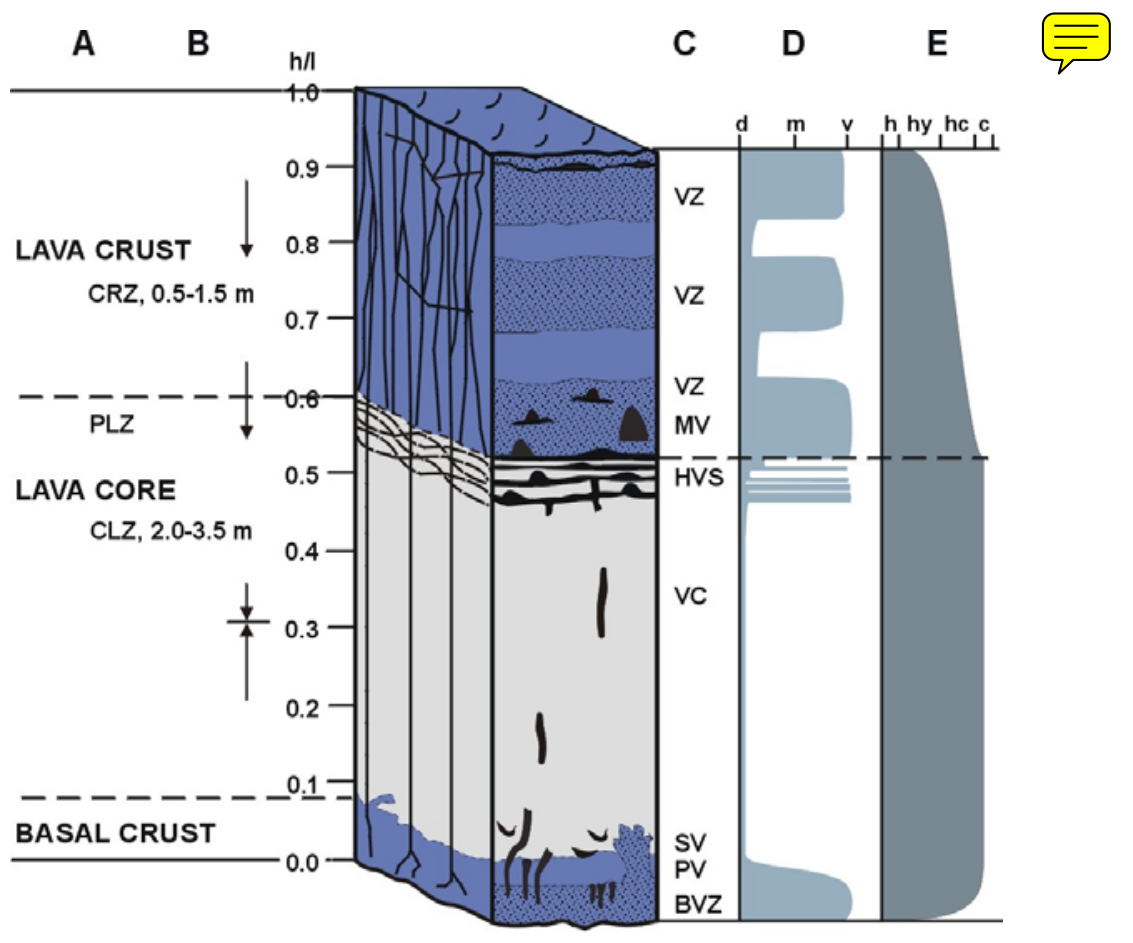



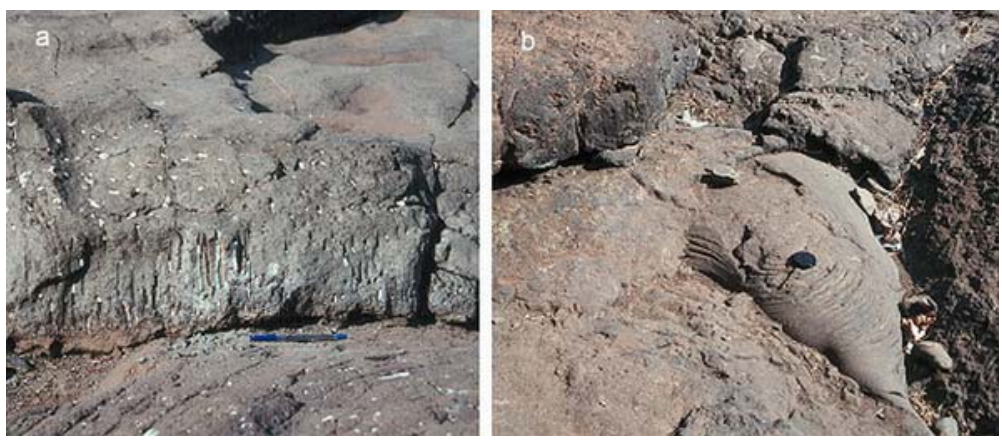

言 


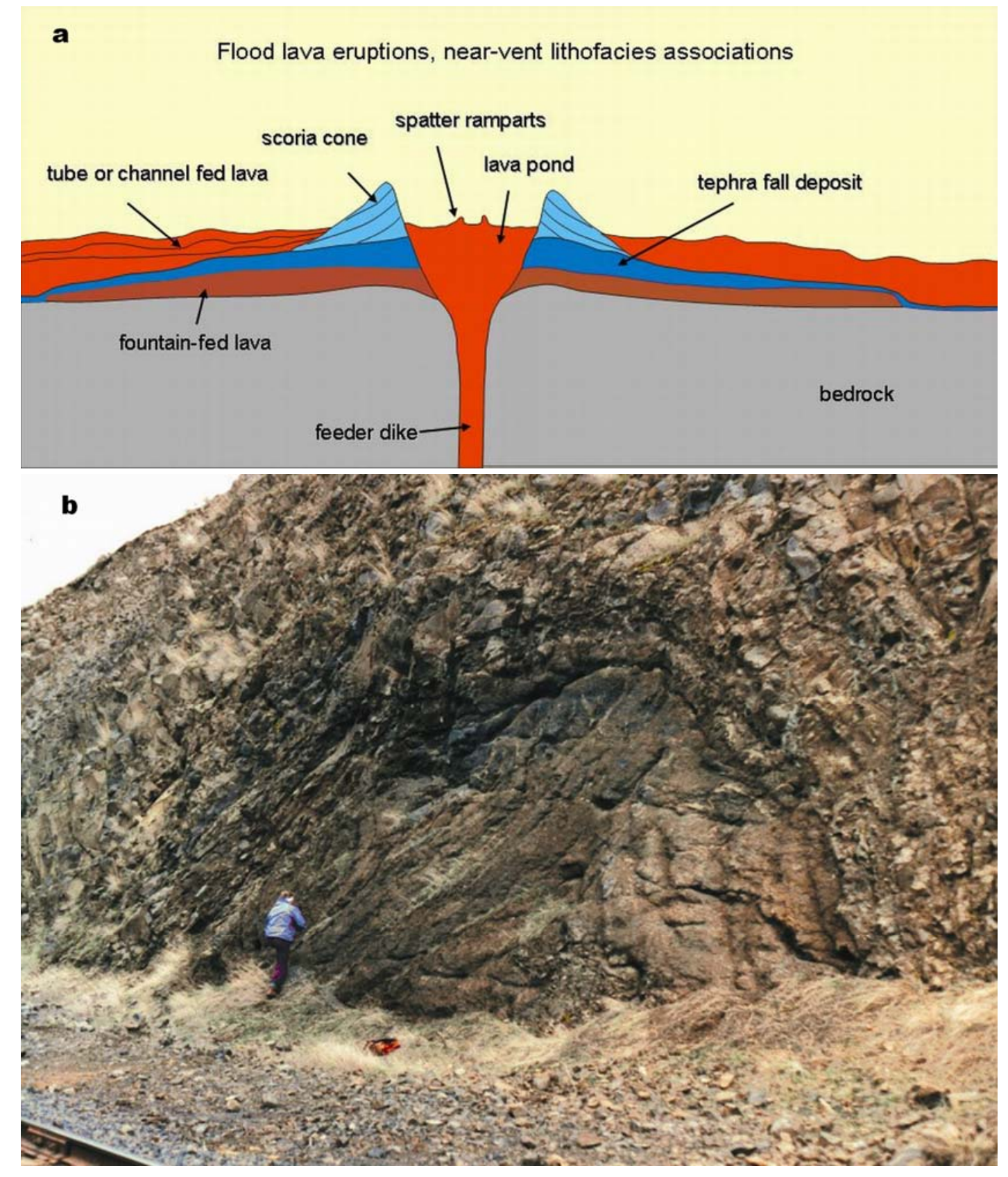




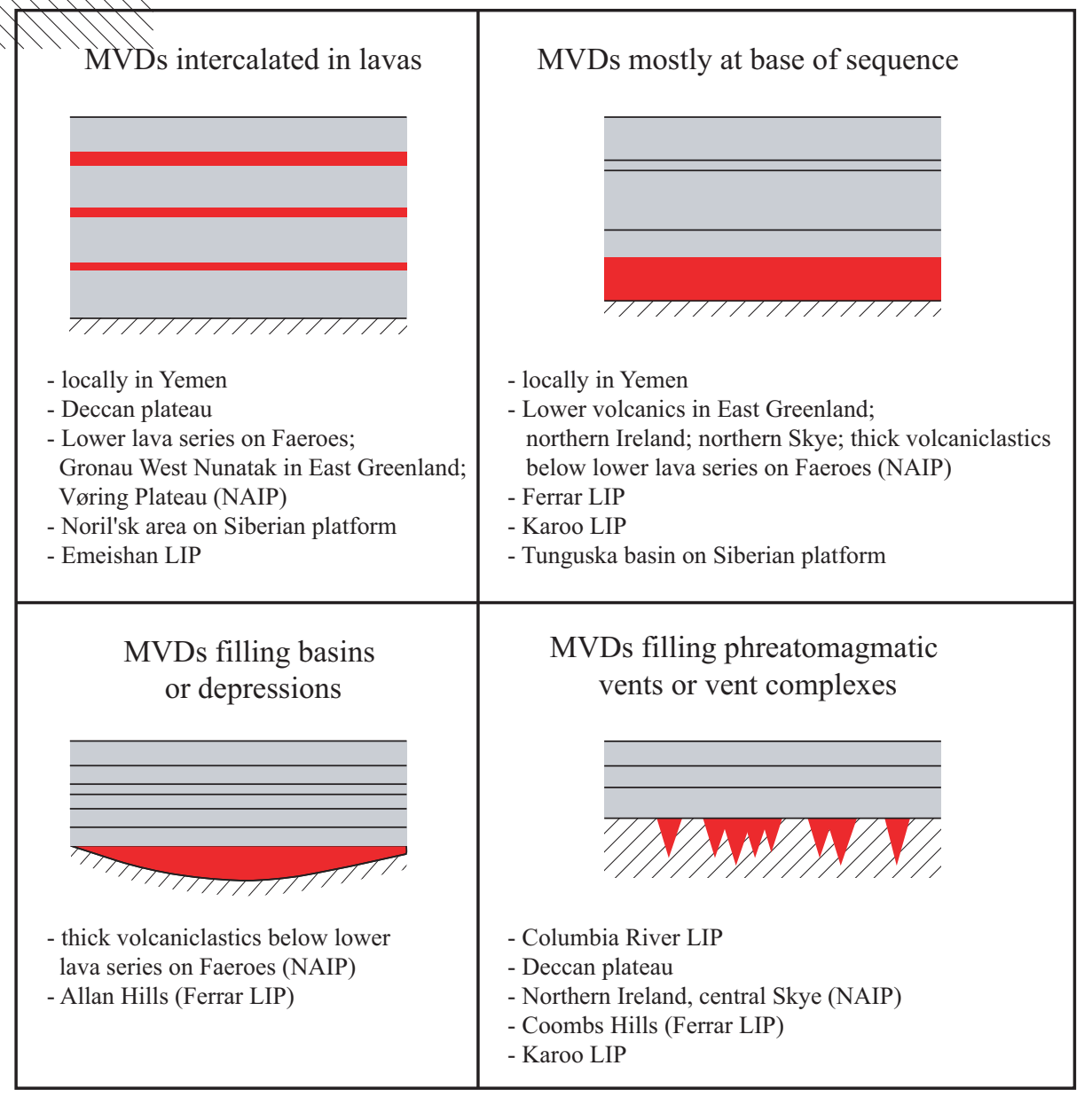


a

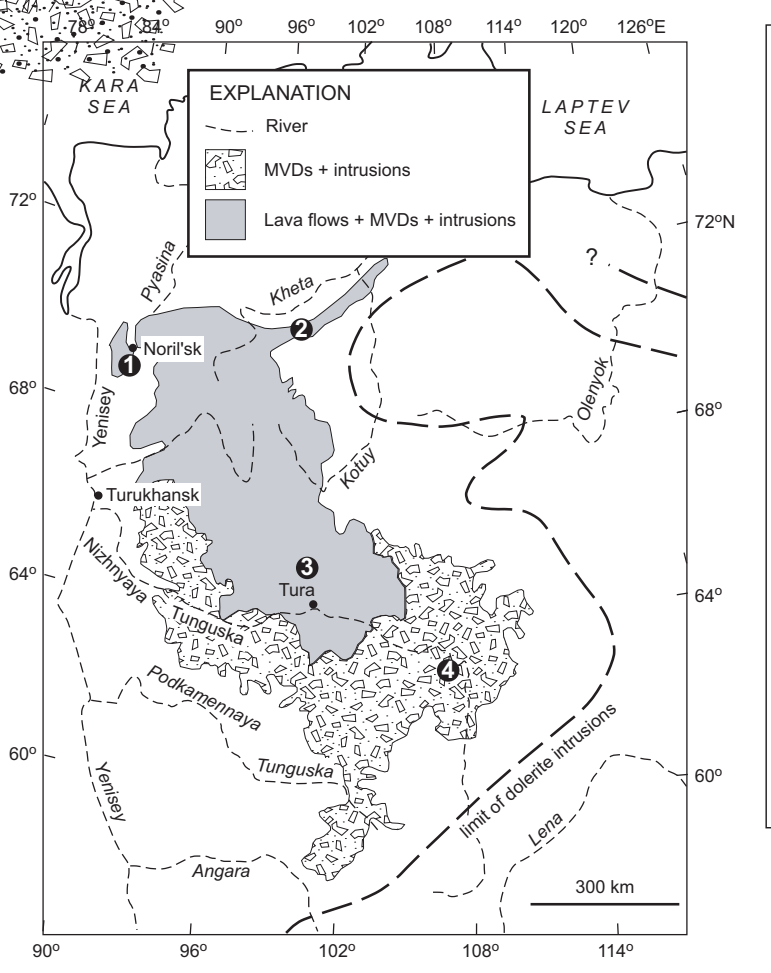

b

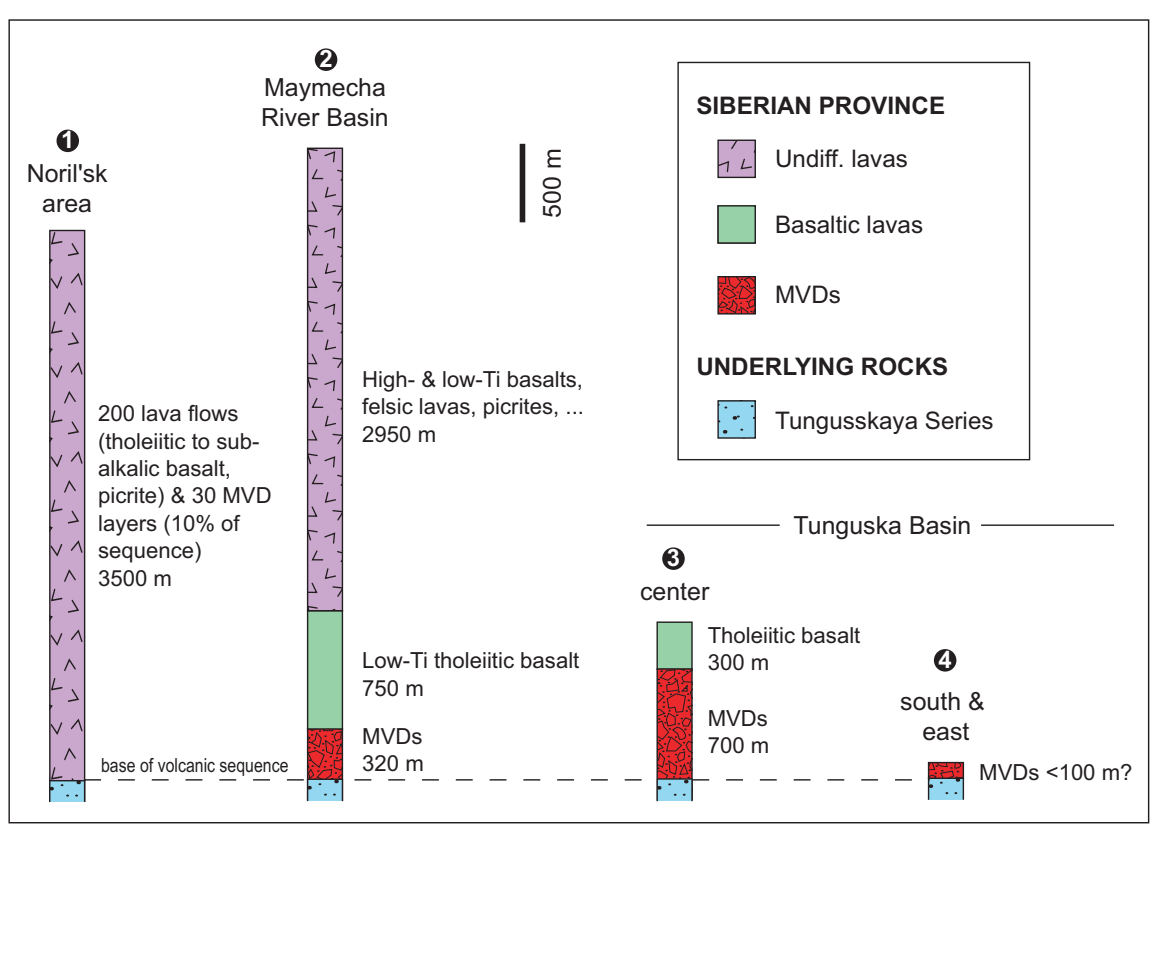


a

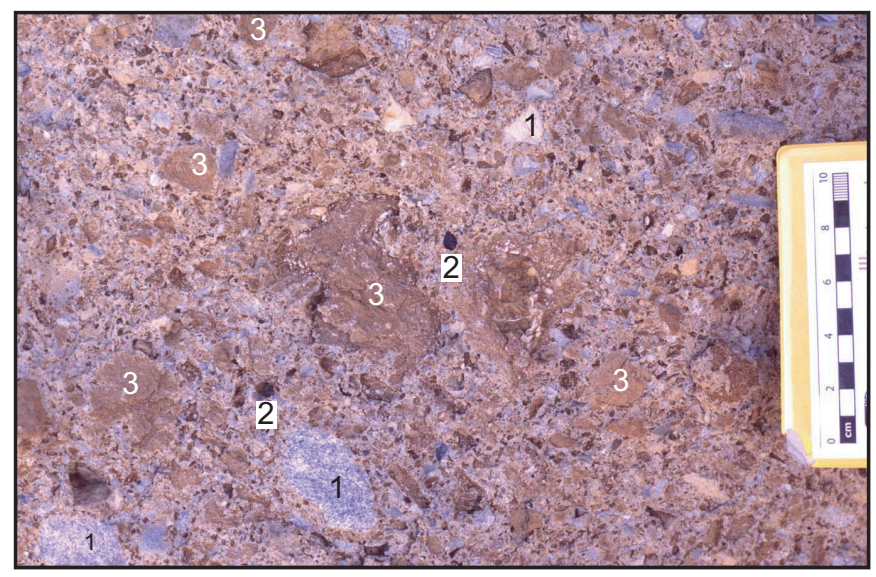

b

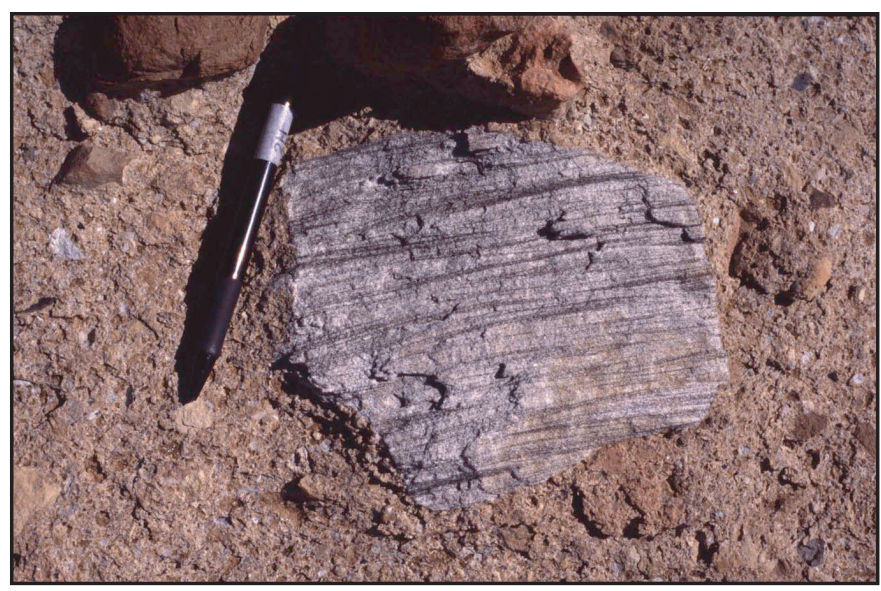

C

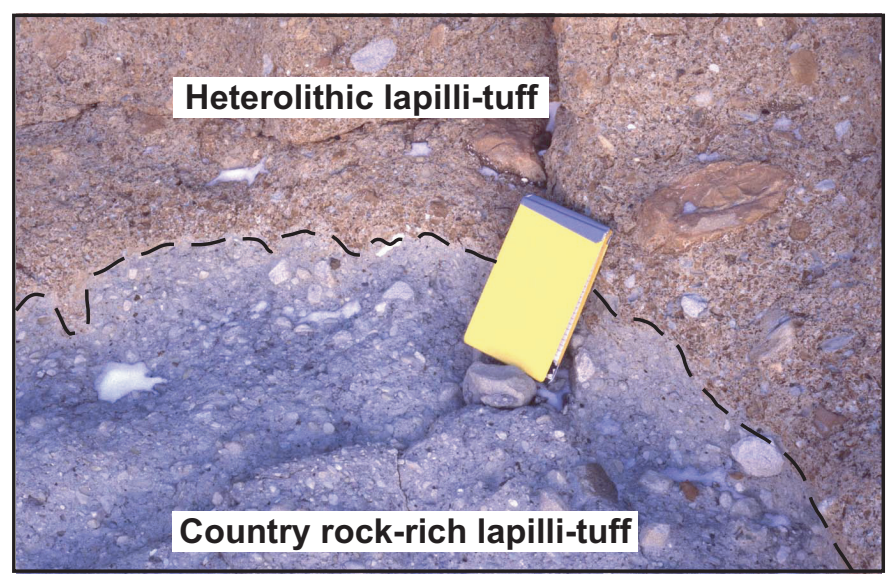

d

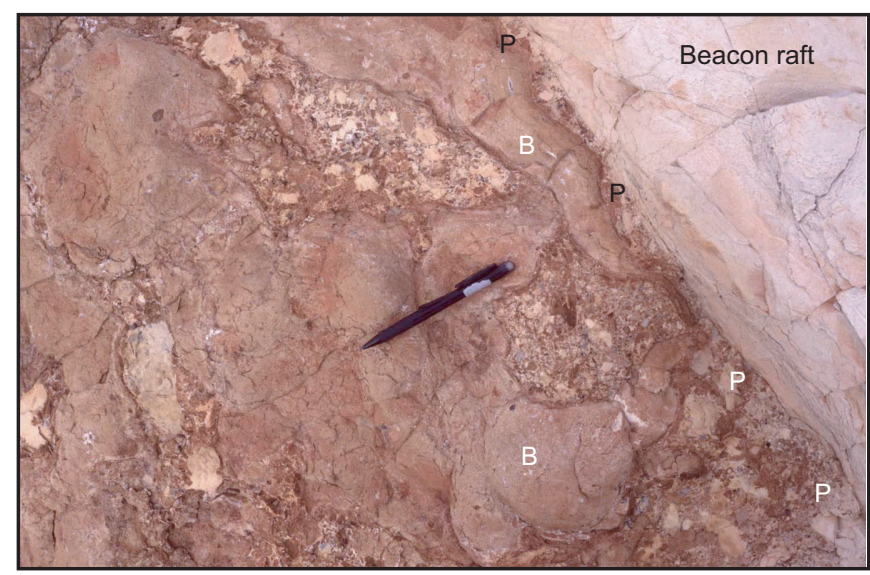

e

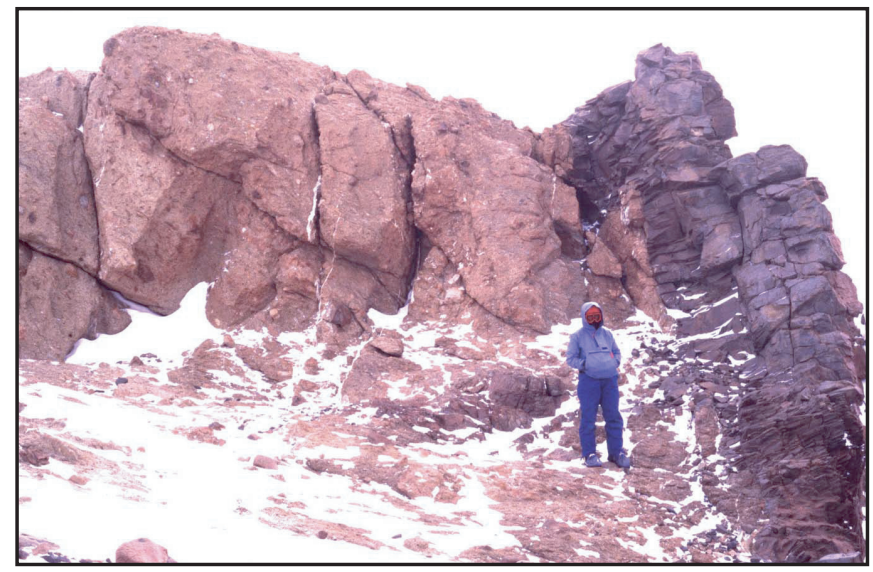

f

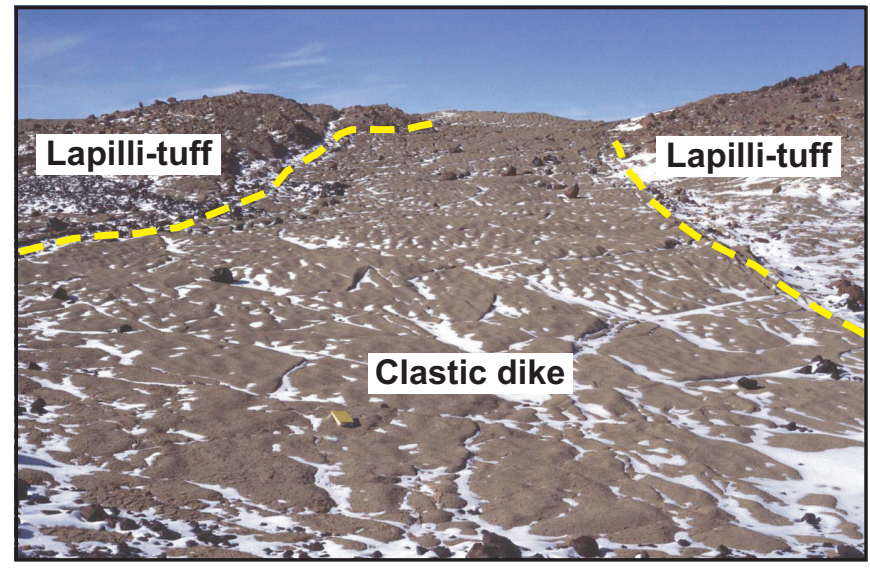


Whitsunday
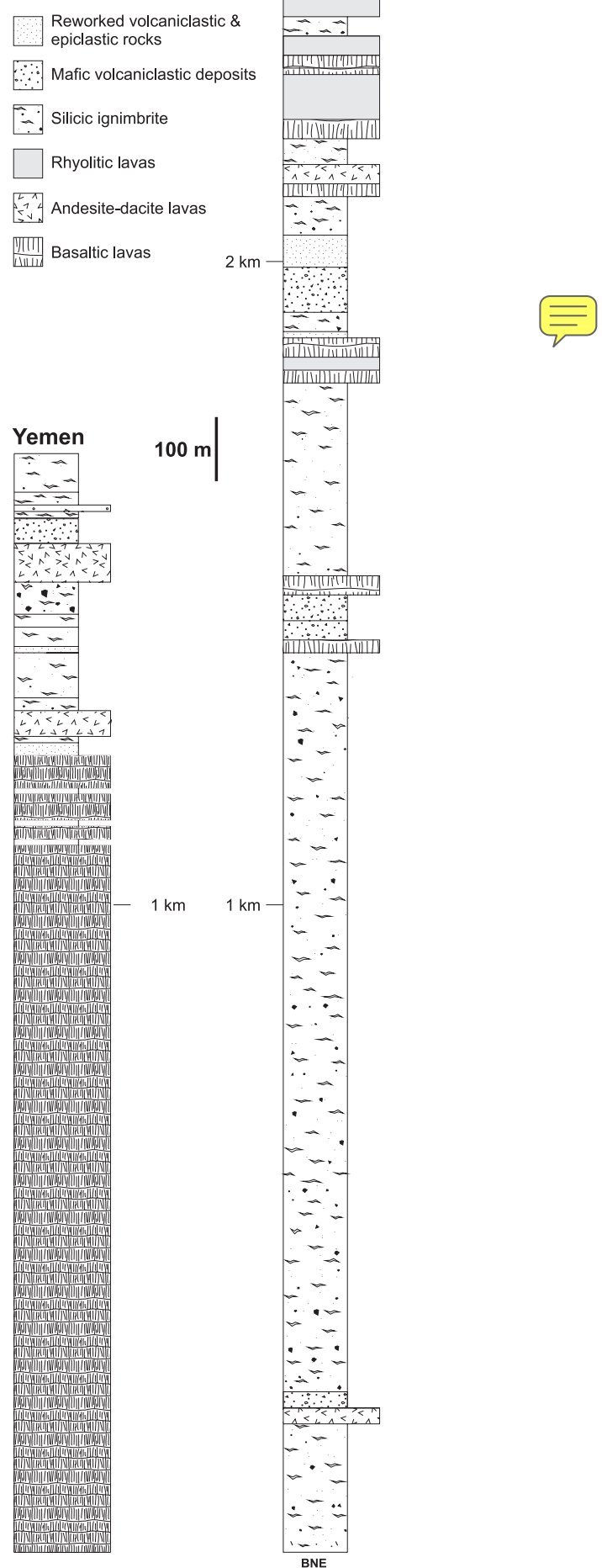